\title{
Assembly of the Cardiac Pacemaking Complex: Electrogenic Principles of Sinoatrial Node Morphogenesis
}

\author{
Marietta Easterling ${ }^{1,2}$, Simone Rossi ${ }^{3}$ (D), Anthony J Mazzella ${ }^{4}$ and Michael Bressan ${ }^{1,2, *(D)}$ \\ 1 Department of Cell Biology and Physiology, University of North Carolina at Chapel Hill, \\ Chapel Hill, NC 27599, USA; m_easterling@unc.edu \\ 2 McAllister Heart Institute, University of North Carolina at Chapel Hill, Chapel Hill, NC 27599, USA \\ 3 Department of Mathematics, University of North Carolina, Chapel Hill, NC 27599, USA; \\ srossi@email.unc.edu \\ 4 Division of Cardiology, University of North Carolina, Chapel Hill, NC 27599, USA; \\ Anthony.Mazzella@unchealth.unc.edu \\ * Correspondence: michael_bressan@med.unc.edu; Tel.: +1-919-843-9455
}

Citation: Easterling, M.; Rossi, S.; Mazzella, A.J; Bressan, M. Assembly of the Cardiac Pacemaking Complex: Electrogenic Principles of Sinoatrial Node Morphogenesis. J. Cardiovasc. Dev. Dis. 2021, 8, 40. https:// doi.org/10.3390/jcdd8040040

Academic Editors: Thomas Brand and Takashi Mikawa

Received: 5 March 2021

Accepted: 5 April 2021

Published: 8 April 2021

Publisher's Note: MDPI stays neutral with regard to jurisdictional claims in published maps and institutional affiliations.

Copyright: (c) 2021 by the authors. Licensee MDPI, Basel, Switzerland. This article is an open access article distributed under the terms and conditions of the Creative Commons Attribution (CC BY) license (https:/ / creativecommons.org/licenses/by/ $4.0 /)$.

\begin{abstract}
Cardiac pacemaker cells located in the sinoatrial node initiate the electrical impulses that drive rhythmic contraction of the heart. The sinoatrial node accounts for only a small proportion of the total mass of the heart yet must produce a stimulus of sufficient strength to stimulate the entire volume of downstream cardiac tissue. This requires balancing a delicate set of electrical interactions both within the sinoatrial node and with the downstream working myocardium. Understanding the fundamental features of these interactions is critical for defining vulnerabilities that arise in human arrhythmic disease and may provide insight towards the design and implementation of the next generation of potential cellular-based cardiac therapeutics. Here, we discuss physiological conditions that influence electrical impulse generation and propagation in the sinoatrial node and describe developmental events that construct the tissue-level architecture that appears necessary for sinoatrial node function.
\end{abstract}

Keywords: sinoatrial node; cardiac pacemaker cell; morphogenesis; conduction

\section{Introduction}

The mature sinoatrial node is a complex, heterogeneous structure located at the junction of the right atrial myocardium and the superior vena cava. It extends posteriorly along the terminal crest towards the insertion of the inferior vena cava (Figure 1A-C) [1]. Since first being described by Keith and Flack in 1907 [2], the sinoatrial node has garnered a significant amount of interest based on its role as the primary pacemaking center of the heart. The sinoatrial node contains a unique class of cardiomyocytes termed cardiac pacemaker cells, which autonomously oscillate membrane potential leading to the rhythmic, spontaneous initiation of action potentials. Pacemaker cells display a wide variation in automaticity, which controls appropriate heart rate in response to various physiologic stimuli, primarily driven by sympathetic and parasympathetic inputs which modulate slow diastolic depolarization time (Figure 1D) [3,4]. Perturbations in sinoatrial node automaticity can be caused by acquired or inherited intrinsic cellular problems, or as the result of extrinsic stimuli such as exaggerated reflex responses or medication side effects. A pooled analysis of 20,572 patients from the Atherosclerosis Risk in Communities Study and the Cardiovascular Health Study reported the incidence of sinoatrial node dysfunction to be eight per 10,000 person-years. Increasing age, greater body mass index, hypertension and concomitant conduction disease were demonstrated to be associated with sinoatrial node dysfunction. Due to increases in these underlying factors, the incidence of sinoatrial node dysfunction is projected to double over the next 50 years [5]. 


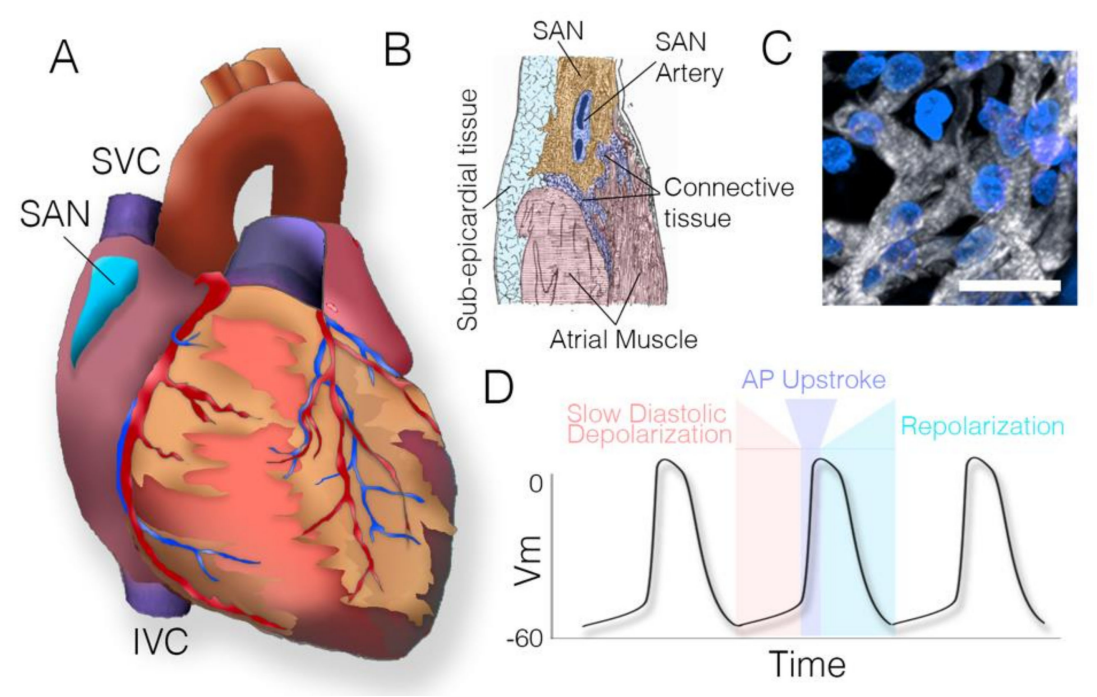

Figure 1. Anatomy and physiology of the sinoatrial node. (A) Diagram of the heart indicating the location of the sinoatrial node (blue). SAN—sinoatrial node, SVC—superior vena cava, IVC_inferior vena cava. (B) Sketch of sinoatrial node structure (modified from Keith and Flack 1907 [2]). Pacemaker myocardium (yellow) surrounds the sinoatrial node artery and is infiltrated and surrounded by connective tissue. (C) $30 \mathrm{~mm}$ Z-stack through the sinoatrial node of an avian embryo. Pacemaker myocardium stained with MF20 (white) is arranged as loosely connected, unaligned fibers. Scale bar-20 mm. (D) Pacemaker cell action potential waveform. Vm-membrane potential.

Sinoatrial node dysfunction is a generalized term that represents a group of conditions, including inappropriate sinus bradycardia, sinus arrest, sinus exit block and tachycardia bradycardia syndromes. In addition to medication side effects and exaggerated vagal tone, degeneration of the sinoatrial node or surrounding atrial tissue can lead to sinoatrial node dysfunction by impeding impulse formation and impulse conduction. The gradual destruction of the sinoatrial node is generally associated with fibrotic remodeling and fatty infiltration leading to sclerodegeneration and eventual senescence [6]. Outside of primary sinoatrial degeneration, the destruction of the nodal-atrial interface or atrial wall can also lead to exit block or damage to the parasympathetic and sympathetic inputs to the sinoatrial node.

The clinical management of symptomatic sinoatrial dysfunction and inappropriate sinus bradycardia first focuses on alleviating secondary causes [7]. This includes removing stimuli that may depress sinoatrial node automaticity, such as exaggerated vagal tone or medications with adverse chronotropic effects. When this is not possible, a permanent transvenous pacemaker may be implanted. Although permanent atrial pacing is usually well-tolerated and associated with low procedural risk in experienced operators' hands, it represents only a reactive treatment rather than a preventative therapy. Unfortunately, preventive therapies currently do not exist. For this reason, increasing emphasis is being placed on constructing a holistic understanding of sinoatrial node function to better predict the conditions that may lead to pathology and/or to formulate novel therapeutic approaches to correct sinoatrial node-related arhythmic disease. Towards this aim, a broad array of physiological [8-10], computational [11,12] and genetic studies [13-16] have built models of how the sinoatrial node's unique cellular and molecular features impact cardiac pacemaker cell activity. The overriding goals of this review are to demonstrate how sinoatrial node morphogenesis creates a specialized microenvironmental niche that supports pacemaker cell function. Towards this aim we first describe some of the basic biophysical conditions that pacemaker cells natively encounter in the heart, outline models of how pacemaker cells are thought to overcome some of the functional barriers to which they are subjected and finally discuss events that occur during sinoatrial node morphogenesis 
that may serve to support the ability of cardiac pacemaker cells to generate and propagate electrical impulses.

\section{Physiological Barriers to Sinoatrial Node Function/Source-Sink Relationships in the Sinoatrial Node}

Estimations in humans suggest that approximately 10,000 pacemaker cells may reside in the central sinoatrial node [17] compared with 2-4 billion working myocytes [18,19]. This fundamental numerical disadvantage places pacemaker cells in a very vulnerable position in which they serve as a small current source for the surrounding working myocardium. This configuration is antithetical to efficient electrical propagation. More specifically, for electrical impulses to successfully conduct through cardiac tissue, a few essential criteria must be met: each cell must be supplied with enough current to reach its depolarization threshold and generate a large enough current flow to activate downstream cells [20,21]. Under conditions in which few cells (such as pacemaker cells) are placed upstream of a large volume of electrically coupled tissue or a current sink (such as the working myocardium), the current generated by the small source rapidly dissipates across the sink before these cells can reach their threshold potential. Additionally, depending on the extent of electrical coupling and the size differential between the source and the sink, ionic gradients that form as the source begins to depolarize can activate local subthreshold current circuits which dampen the ability of the source to accumulate the charge needed to fire an action potential [21-23]. Theoretically, this would be predicted to prolong the time it takes for the source cells to reach threshold potential, delaying or potentially suppressing electrical impulse initiation. Under these conditions, a self-sustaining action potential cannot be achieved, resulting in propagation failure or block. Conduction failures of this form are often referred to as a source-sink mismatch. Based on the native source-sink relationships present between the sinoatrial node and working myocardium, the obvious question becomes how do the small numbers of pacemaker cells present in the heart drive cardiac activation [24]?

Indeed, dating back to the earliest computational models describing interactions between pacemaking cells and working myocardium, it has been appreciated that unique electro-anatomical features must be present to support the native activity of the sinoatrial node [24]. In a broad sense, we can describe the mechanisms by which pacemaker cells escape suppression as both increasing their efficiency to serve as a source and decreasing the hyperpolarizing load of the sink. As described below, several interrelated models have emerged that can be thought of as contributing to these parameters.

\section{Electro-Anatomical Features That Support Sinoatrial Node Function}

\subsection{Synchronization}

Cardiac pacemaker cells do not function in isolation and are often modeled as a system of coupled electrical oscillators [25-28]. As such, the dynamics of their network-level behaviors define the amount of ionic current that can be generated and serve as a source to adjacent tissue. Somewhat paradoxically, however, experimental observations have demonstrated that individual pacemaker cells have varying rates of activity, rhythmicity and current densities [29-32]. Thus, if considered as isolated units, each cell's ability to autonomously oscillate charged ions would lead to complex and potentially detrimental electrical interactions. At any given time, different populations of pacemaker cells would be polarized, depolarizing or repolarizing, disrupting the required electrochemical gradients needed for action potentials to propagate in a coherent fashion and/or introducing potentially out-of-phase impulses leading to arrhythmia. To overcome this, networks of pacemaker cells synchronize to a common frequency [33] such that individual cells are at compatible states in their oscillatory phase throughout the process of electrical impulse generation. This increases the volume of cells available to serve as an electrical source for activating the adjacent working myocardium while also satisfying the basic conditions required for impulse propagation. Furthermore, evidence suggests that synchronization 
helps maintain the stability of biorhythmic activity. Work from Clay and Dehaan demonstrated that increasing the numbers of entrained spontaneously active cells decreases the potential influence of stoichiometric fluctuations in ion channel activity. Random electrical noise would be predicted to impact the rate and rhythmicity of individual cells significantly. However, this effect can be mitigated as more cells are added and entrained within the system [34]. Thus, synchronization is a critical functional characteristic of pacemaker cells, and the heart's pacemaking complex can be thought of as collectives of thousands of cells activating in unison.

In determining how systems of oscillators entrain, the possible phase of each oscillator, the frequency variation within the population and the magnitude of information shared between units need to be considered [26,35,36]. In the context of pacemaker cells, these parameters would be most equivalent to variations in the waveform of the action potential, the offset of the action potential phase and the extent of electrical coupling between cells. Indeed, studies have shown that each of these features is interdependently modulated among pacemaker cells as they coalesce towards synchronization, with the strength of electrical coupling between cells appearing to be the primary driver of this process [37]. As each pacemaker independently oscillates, small amounts of current flow back and forth between them, altering the native periodicity of each cell and resulting in advancement towards a common frequency. Indeed, Anumonwo et al. demonstrated that the application of a brief external current can change the phase characteristics of individual pacemaker cells. This established that subthreshold electrical interactions among collections of pacemaker cells could alter the spontaneous cycle length of each cell in the system, driving populations of pacemaker cells towards mutual entrainment [38]. Furthermore, multiple studies have noted systems of discreet entrained behaviors emerge as coupling characteristics are altered among pacemaker cells. At low levels of coupling, pacemaker cells display independent oscillation. As coupling is progressively increased: (1) dynamic patterns of entrainment with varying frequency emerge, (2) 1:1 frequency entrainment with differing action potential waveforms is achieved and (3) finally, at relatively high coupling conductance, pacemaker cells display 1:1 frequency entrainment with matching waveforms. The absolute values of coupling needed to reach each behavioral regime vary slightly depending on the differences of the innate waveforms and periodicities that need to be overcome within the starting populations $[39,40]$. Thus, to achieve synchronization, cells with similar phase and frequency features require lower coupling than cells with more divergent starting characteristics.

It should be emphasized that synchronization denotes that the system of cells becomes entrained to a stable periodicity, not necessarily that all cells match the rate of any individual cell's activity. Multiple studies have indicated that the rate at which systems of pacemaker cells synchronize is a complex function of the independent activities of the coupled cells and not merely a convergence to the cycle length of the fastest cell in the system [37-43]. For example, Mata et al. showed that the more heterogeneous cardiac pacemaker cells (CPCs), the shorter the cycle length at which they synchronize [43]. Furthermore, the process of synchronizing oscillatory rates does not necessarily imply that all cells in the system fire at the same time. Michaels et al. demonstrated that slight temporal differences in the phase of synchronized pacemaker cells can replicate the slow activation pattern typically associated with the sinoatrial node. In this study, the authors simulated fields of pacemaker cells in a two-dimensional array and noted synchronization occurred in a phase and couplingdependent manner, as described above. Interestingly, propagating wavefronts were noted among the collections of synchronized cells. However, these wavefronts were not the direct result of action potential conduction but were due to discrepancies in the phase of the synchronized pacemaker cells. Thus, the slight offset in the activation times of synchronized cells gave rise to a region of central activation and a wave of depolarization that moved radially outward [44].

Collectively, studies related to the mechanisms of synchronization have thus far uncovered a trend towards uniform firing through a process of democratic mutual entrainment 
at sufficient coupling values. Additionally, these studies indicate that entrainment is not merely restricted to rates of activity but can also extend to the precise matching action potential waveform characteristics and give rise to intricate activation patterns. As such, the process of synchronization is critical for maximizing the number of cells that effectively serve as a source of charge for activating the downstream working myocardium.

A major challenge for studying synchronization of cardiac pacemaking activity is the multiscalar and heterogeneous nature of the sinoatrial node. Furthermore, the influence of the coupled atrial tissue is not typically considered when examining the process of synchronization. As described below, computational treatments of sinoatrial node function are continually adding increased complexity to our view of heterogeneity, including variations in gap junctional conductivities, ion channel conductance [45], cellular make up [46,47] and cell-to-cell connectivity [43]. In particular, recent models introduced by Gratz et al., Ly and Weinberg, Mata et al., and Sehgal et al. may be able to account for all these features in future analysis of synchronization $[43,45,46,48]$.

\subsection{Sinoatrial Node Structure-Interstitial Fibrosis}

One of the defining histological characteristics of the mature sinoatrial node is the presence of large numbers of nonmuscle, fibroblast-like cells surrounding and interdigitated among the disorganized, unaligned pacemaker myocardium [49-52]. Studies have revealed the muscle/fibroblast ratio in the sinoatrial node varies between species, with mice displaying relatively low fibrotic content ( $25 \%$ in adults) [53,54]. In comparison, pigs can show greater than $70 \%$ fibrotic content [49] while felines can display upwards of $90 \%$ fibrotic content in their sinoatrial node [55]. Furthermore, the fibrotic content of the sinoatrial node is not static and tends to increase with aging. Reports in humans indicate that fibrous connective tissue ranges from approximately $25-40 \%$ of the sinoatrial node in infants and children to greater than $70 \%$ in adulthood $[55,56]$.

Despite the elevated connective tissue distribution in the sinoatrial node, mechanistic details outlining a direct relationship between fibrosis and pacemaker activity have remained challenging to demonstrate experimentally. Kohl et al. suggested that stretchdependent activation of fibroblast ionic currents may raise the rate of pacemaker cell activity when these populations are electrically coupled [57]. Oren et al. proposed that fibroblasts may act as current sinks, conduction obstacles or establish independent conduction pathways supporting sinoatrial node activity. This work emphasized that the role of the fibroblast populations is largely dependent on their density, distribution, and the nature of their potential electronic interactions with pacemaker cells [58]. Karpaev et al. developed a computational model that considers the interaction between center and peripheral pacemaker cells, atrial cells and fibroblast interconnected via gap junctions [47]. In this work, it was determined that a sinoatrial node consisting of only myocytes fully activated in less than $8 \mathrm{~ms}$ and failed to reproduce known central-to-peripheral propagation patterns observed in electrophysiological recordings of the sinoatrial node. By including fibroblasts electrically coupled with pacemaker cells, activation sequences consistent with those observed in vivo could be generated [47]. In support of this, studies have demonstrated that fibroblasts coupling can lead to the depolarization of myocytes $[59,60]$, which, if extrapolated to pacemaker cells, might be predicted to protect against the hyperpolarization of the sinoatrial node. In additional studies, Miragoli et al. further demonstrated that myofibroblasts can induce spontaneous automaticity in otherwise senescent working myocytes, indicating that fibroblasts may support oscillatory behavior [61]. The above studies collectively imply direct electrical coupling between fibroblasts and pacemaker cells. There is some support for this idea in that lucifer yellow loading into sinoatrial node fibroblasts appeared to show spread into pacemaker myocardium [62]. Furthermore, cardiac fibroblasts express gap junctional proteins, including Connexin 43 and Connexin $45[59,63]$. However, if functional gap junctional coupling is present between pacemaker cells and fibroblasts, it would seem very rare within the sinoatrial node, as such junctions are not readily detected through ultrastructural analysis [64]. Collectively, the studies 
above indicate that sinoatrial node fibroblasts may play a role in modulating pacemaker cell excitability via cell-cell electrical interactions. However, further work is required to validate this idea in vivo.

Beyond a proposed direct role in the modulation of pacemaker cell electrical activity, sinoatrial node fibroblasts likely contribute to the sinoatrial node's overall tissue-level biophysical properties. Herein, principles of discontinuous propagation would apply. Somewhat counterintuitively, this principle suggests the safety factor for propagation will increase as action potentials encounter regions of high electrical resistance [20]. For instance, work from Joyner et al. using numerical modeling demonstrated under the circumstance in which small numbers of cells must electrically drive large volumes of myocytes (such as the sinoatrial node/atrial boundary or the purkinje fiber/ventricular myocardial interface), resistive barriers can support propagation $[65,66]$. This theory was also demonstrated in work from Rohr et al. using cultured neonatal rat ventricular myocytes. Here it was shown that electrical propagation at sites of abrupt myocardial expansions (such as the sinoatrial node atrial boundary) was supported by discontinuities that lower cellular coupling [67]. As such, nonexcitable fibroblasts, and the extracellular matrix they deposit in the sinoatrial node, may function as resistive barriers that establish discontinuities in sinoatrial node conduction. This would support pacemaker cell excitability by preventing current dissipation during the slow diastolic and/or upstroke phase of pacemaker action potential generation. Thus, by creating a unique microenvironment, sinoatrial node fibrosis may provide direct biophysical support for pacemaker myocardium.

\subsection{Sinoatrial Node Structure-Atrial Interface}

A comprehensive review on sinoatrial node (SAN)/atrial coupling can be found in Joyner, Wilders and Wagner [11]. Below, we introduce some of the critical principles underlying this interaction. When the influence of the electrical load placed on the sinoatrial node by adjacent atrial tissue is modeled, the existence of three possible scenarios emerge: (1) no pacing, in which cardiac pacemaker cell electrical activity is entirely suppressed by the atrial myocardium, (2) pace but no drive, in which pacemaker cells can initiate an action potential but cannot stimulate the atrial tissue and (3) pace and drive, in which pacemaker cells generate an electrical impulse that successfully propagates to the atria $[24,68]$. In general, modeling has again highlighted coupling conductance within the sinoatrial node and/or between the sinoatrial node and the atria as the major determinants of successful propagation. When coupling conductance is large, the atrial cells hyperpolarize the sinoatrial node, and pacemaker cells are inhibited from reaching threshold membrane potentials, thus blocking action potential initiation (no pacing). When coupling conductance between the sinoatrial node and atria is too small, pacemaker cells display rhythmic activation but cannot transmit impulses to the atria (pace but no drive). Only for intermediate values of conductance can the sinoatrial node both sustain the capacity to fire an impulse and propagate it to the atria (pace and drive). Of note, the values of intermediate coupling for pacemaker cells in this case are still relatively low (2.6-7.5 nS) [69-71] when compared to the junctional conductance present in the atrial and ventricular working myocardium, which are between $\sim 10-100$ times higher $[72,73]$. Thus, it is generally accepted that the sinoatrial node must tightly regulate its level of coupling within a narrow range to sustain function. However, the mechanisms by which coupling is controlled on a macroscopic scale in and around pacemaker cells appear varied and complex [74].

Various models have been put forth to describe the possible means by which pacemaker cells mediate their electrical interactions with the atrial working myocardium. One such hypothesis suggests that there is a graded transition of phenotypic characteristics within the sinoatrial node. In this gradient model (Figure 2A) there is one distinct pacemaker cell type in the central sinoatrial node and a smooth transition in properties from the central sinoatrial node to its periphery [71,75]. Thus, characteristics such as ion current densities, coupling conductance and cell size vary through this continuum of phenotypes, allowing for ramping up properties such as junctional conductance (very low in the central 
sinoatrial node to relatively high at the periphery) [24,76]. An alternative model, known as the mosaic model (Figure 2A), postulates two populations of myocardial cells in the sinoatrial node (pacemaker and atrial cells), each with reasonably uniform properties (cell size and ionic currents, coupling, etc.). In this model, the percentage of each cell type in the various regions of the sinoatrial node dictates the localized electrophysiological properties. For example, junctional conductance would be relatively low in the central sinoatrial node because there are few atrial-like cells present. In contrast, these values increase towards the periphery because the percentage of atrial-like cells increases [39]. Although many authors have rejected the mosaic model based on comparison with experiments in rabbits [77], more recent computational simulations have used the mosaic model to elicit successful atrial pacing [78].
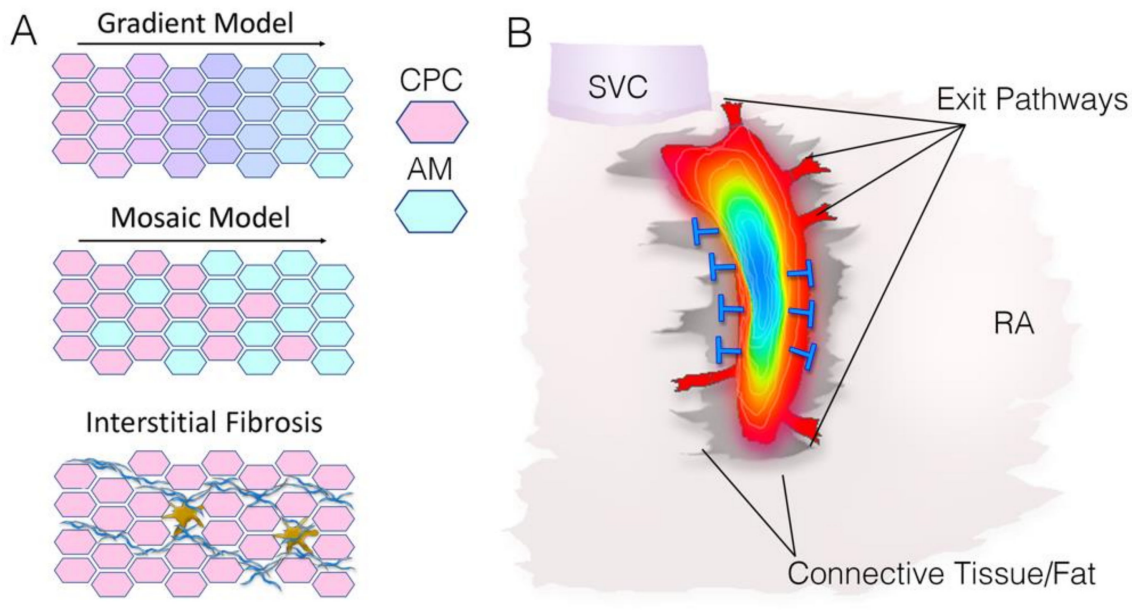

Figure 2. Models of sinoatrial node structure/function. (A) Graphical depictions of the Gradient Model, the Mosaic Model, and Interstitial Fibrosis. CPC—cardiac pacemaker cell, AM-atrial myocyte. (B) Diagram of sinoatrial node activation pattern (blue to red). Potential exit pathways to the atrial myocardium and connective tissue (grey) that serve as resistive barriers (blue lines) are indicated. SVC - superior vena cava, RA—right atrium.

A still more elaborate description of the sinoatrial node/atrial boundary includes the existence of potential exit pathways (Figure 2B). This model is based on observations that the sinoatrial node in some species appears to be broadly surrounded by regions of fibrosis and fat with only a few discrete muscular connections linking pacemaker cells to atrial myocytes [79-82]. In theory, limiting the size of the interface between the sinoatrial node and atrial myocardium by having only a few discreet exit pathways would minimize the electrical load on the primary pacemaker cells, giving them sufficient time to build up the charge required to excite the atria [83]. In support of this, ablation of potential exit pathways has resulted in the sinoatrial node exit block [79]. High resolution functional and structural mapping of the adult sinoatrial node has lent support for this model $[84,85]$ and three to five discrete branching myofiber tracts, located near the superior vena cava, interatrial septum and laterally atrial muscle, have been described $[85,86]$. Potential exit pathways are thought to be composed of transitional cells with morphological and functional characteristics between that of pacemaker and atrial cells [83]. While the existence of exit pathways has been documented in rabbit [71], dog [79,82] and human [84], several human studies have not found insulating fibrous barriers surrounding the sinoatrial node with defined exit sites [87-90]. In the work of Ho and Sánchez-Quintana, only some human hearts had a fibro-fatty tissue barrier between the node and the subendocardial myocardium [87]. Therefore, it has been suggested that exit sites may be functional, as opposed to anatomical features, of the sinoatrial node/atrial interface [91].

Computational studies have demonstrated that aspects of the gradient models, mosaic models and exit pathway models can each achieve functional pacemaking. Among the first 
mathematical investigations of the sinoatrial node/atrial interface was work conducted by Joyner and Capelle [24]. Using a radial description of the sinoatrial node, the authors were able to demonstrate that propagation from a central sinoatrial node region (with high intercellular resistance) to atrial tissue (with low intercellular resistance) was most efficient when a gradual transition in resistance was applied through the periphery of the sinoatrial node. Expanding on this, a study by Inada et al. modeled cells with graded phenotypic features (current densities, size, junctional conductance) from a central to a peripheral manner consistent with values recorded in the rabbit sinoatrial node [76]. This graded approach replicated critical features of sinoatrial node activation, including cycle length, activation and repolarization sequences and action potential waveforms. Using a mosaic model, which accounted for the geometric arrangement of pacemaker/atrial cells reported in Csepe et al. [84], Garza et al. were able to demonstrate that features consistent with graded phenotypes can emerge even in the absence of innate transitional phenotypes. However, this study does not account for observed phenotypic differences that have been noted among cells isolated from the sinoatrial node [78]. Kharche et al. generated a threedimensional model of the sinoatrial node that considered a fibrotic border, a paranodal area and exit pathways [92]. To initiate electrical wave propagation close to the centroid of the 3D sinoatrial node, a gradient of the gap junctional conductance was required. Thus, a combination of the exit pathway and the gradient model were found effective in these 3D simulations. Collectively, these reports indicate multiple configurations of the sinoatrial node can support function. Indeed, variations in sinoatrial node architecture that have been noted across different species may suggest that one unified theory of a pacemaker cell/atrial interface may not be appropriate, and that elements of each of the above models may contribute to pacemaker function under different circumstances.

\section{Sinoatrial Node Morphogenesis}

One unfortunate aspect of the above models is that they are difficult to assay experimentally. For instance, altering conductance and/or modifying the fibrotic content specifically in the adult sinoatrial node is challenging. However, the increasing array of tools available to manipulate the heart during embryological development may be able to bridge some of the gaps between theory and application. For this to be effective, we require a precise spatiotemporal understanding of the micro and macroscopic embryonic assembly of the heart's pacemaking complex. Therefore, in the following sections, we describe pacemaker cell development, highlighting studies that are starting to provide insight into the events underlying sinoatrial node morphogenesis.

\subsection{Pacing in the Early Heart}

During early cardiogenesis, the heart initially forms as a simple contractile tube. This tube displays innate electrical automaticity, as juvenile cardiomyocytes near the inflow segment of the tube spontaneously initiate action potentials that propagate towards the outflow [93-95]. However, the early pacing centers in the looping stage heart do not represent the progenitors of the mature sinoatrial node. Indeed, it appears that the location of the early pacing centers of the heart continuously shifts as the heart tube extends and elongates $[95,96]$. Direct labeling studies have confirmed that the pacemaking function is progressively assigned to new populations of myocytes as they are added to the venous pole of the heart. During these stages, bona fide sinoatrial node pacemaking cells reside as undifferentiated mesenchyme located posterior (in chick) or lateral (in mouse) to the primary heart tube $[95,97,98]$. The shifting of pacemaking activity continues until the late stages of looping morphogenesis, at which point myocardium located in the wall of the newly formed sinus venosus (along with the right inflow venous return of the heart) become electrically active, begin expressing functional markers of the pacemaker lineage and take on pacemaker cell functional characteristics [14,95,99-106]. These inflow myocardial cells go on to give rise to the pacemaker cells of the sinoatrial node [95]. 
Of note, fibrotic characteristics reminiscent of the mature sinoatrial node are not detected around the transient pacemaker populations during cardiac looping stages. These regions are structurally indistinguishable from their neighboring myocytes [94]. Despite this, the transient heart tube stage pacemaker centers still function. This functionality can be attributed, at least in part, to the electrophysiological properties of the early heart tube. For example, maximal diastolic depolarization in the linear heart has been reported at around $-40 \mathrm{mV}$, which increases to greater than $-70 \mathrm{mV}$ by the completion of cardiac septation $[107,108]$. Therefore, the hyperpolarizing load of the heart tube in relation to the transient pacemaker centers is lower than in the more mature embryonic heart, which would be predicted to lessen source-sink burdens. Similarly, the conduction velocity in the heart tube is far lower than later stages or the adult heart [109]. While this can be partially explained by low sodium current $\left(I_{\text {na }}\right)$ in the younger heart [108], it is also likely due to the relative lack of intercellular gap junctional coupling. Indeed, the transcript levels of high conductance gap junctions, such as Connexin 40 and Connexin 43, are relatively low in the early heart tube [109]. Both transmission and freeze-fracture electron microscopy have indicated that early cardiomyocytes display gap junction to plasma membrane ratios far lower than their looping and septation stage counterparts $[110,111]$. Due to the lack of high conductance pathways between cells, the safety factor for propagation should be favorable for action potential initiation and propagation in the heart tube, as only a small fraction of the incoming depolarizing current would be lost to downstream cells.

Towards the end of looping morphogenesis (E9.5-E10 in mouse, E3 in chick), myocytes that will contribute to the mature sinoatrial node take over as the dominant pacemaker cells in the heart $[95,97,99,100,104,112-114]$. These newly differentiated pacemaker cells must drive a larger population of chamber myocardium than was present at earlier linear heart tube stages, and are confronted with electrogenic conditions that are less optimal. Specifically, maximal diastolic depolarization becomes progressively more negative during these stages as the working myocytes mature and gap junction expression and density increase [107-111]. Therefore, it would be expected that conditions present in the mature sinoatrial node thought to protect pacemaker cells from unfavorable electrical interactions with the adjacent working myocytes should manifest rapidly as pacemaker cells are added to the heart. Indeed, from the earliest stages of sinoatrial node pacemaker cell activity, these cells show lower transcript levels of Connexin 40 and Connexin 43 than the atrial myocardium to which they are connected $[95,97,99,100,104,112-114]$. Consequently, repression of gap junction transcription is believed to electrically insulate pacemaker cells right from the initial time point when they begin interacting with downstream atrial myocardium. However, the mature sinoatrial node's structural features thought to help protect pacemaker function, including the presence of nonexcitable fibroblasts and higher extracellular matrix (ECM) content, are not present at these stages [104,115,116]. Instead, the tissue-level architecture of the sinoatrial node is built around the pacemaker myocardium after these cells have already taken on their physiological role of stimulating the downstream myocardium. It is with the rearrangement and the establishment of the surrounding microenvironment that features consistent with the mature sinoatrial node begin to arise.

\subsection{Formation of the Pacemaker Cell Microenvironment}

Despite the variety of potential physiological roles that fibroblasts may play in pacemaking function, and the apparent conservation of their presence in the mammalian and avian sinoatrial node, the developmental patterning events that lead to the unique density of these cells found around pacemaker cells have only begun to be investigated. As described above, during the earliest stages of pacemaker cell activation in the embryonic heart, fibroblast-like cells are not detectable among pacemaker myocardium. However, it has recently been demonstrated that the tissue-level architecture of the forming sinoatrial node rapidly changes over cardiac developmental stages following pacemaker cell differentiation. During this period, the forming sinoatrial node remodels from a thin walled, densely packed collection of pacemaker myocardium, into loosely connected clusters or 
strands of cells surrounded by nonmuscle mesenchymal cells (Figure 3A). This functional reorganization occurs over an approximately three-day developmental window in avian (spanning E3-E6) [104]. Notably, the tissue-level morphological changes observed in the forming avian sinoatrial node seem to be preserved as they can also be tracked in mice [104].

Remodeling of the sinoatrial node region is driven, at least in part, by the integration of cells derived from an adjacent structure known as the proepicardium [104]. The proepicardium is a transitory, multipotent, embryonic tissue that forms along the anterior, ventral aspect of the junction between the liver bud and the inflow myocardium in which pacemaker cells reside [117-120]. Classically, cells from the proepicardium are described as extending and/or budding into the pericardial space between the liver bud and the atrioventricular myocardium. Proepicardial cells then bind to and spread over the myocardium giving rise to the epicardial layer of the heart. Subsequently, proepicardialderived cells invade the myocardium contributing to cardiac lineages including fibroblasts, vascular endothelium and coronary smooth muscle [118]. Cell tracing studies in both chick and mouse have demonstrated that in addition to this traditional view of proepicardial migration, proepicardial-derived cells also rapidly and specifically invade the pacemaker myocardium at the end of looping morphogenesis [104]. Indeed, these cells can be seen wrapping around pacemaker cells, physically segregating them into unaligned, loosely connected clusters [104].

The incorporation of proepicardial cells into the sinoatrial node and their effect on pacemaker cell distribution creates a tissue architecture very analogous to the patchy fibrosis noted during the pathological remodeling of the ventricular myocardium. When viewed from the perspective of ventricular electrophysiology, creating regions of patchy fibrosis disrupts the three-dimensional syncytial nature of the myocardium. As reviewed by Nguyen et al., this can be modeled as creating interacting tangles of quasi-1D myocardial cables [122]. By adjusting the electrical connectivity of these cables from a 3D syncytium to 1D cables, source-sink relationships and the ability of the surrounding tissue to suppress spontaneous electrical activity decreases. Indeed, estimates for the number of cells required to generate enough current to stimulate an ectopic action potential in healthy $3 \mathrm{D}$ ventricular myocardium is on the order of 700,000 myocytes firing in synchrony [123,124]. However, by altering the tissue structure through fibrotic remodeling, this estimate drops by several orders of magnitude [122,124]. Patchy fibrosis is viewed as a significant predisposing factor to arrhythmogenic potential in the ventricles. However, when viewed from the perspective of pacemaker cell function, this form of fibrotic remodeling would be beneficial, lowering the number of pacemaker cells required to serve as a current source for the rest of the heart. In support of this, blocking proepicardial cell invasion into the forming sinoatrial node prevents structural remodeling leading to electrical failure (Figure 3B,C). Following proepicardial removal, pacemaker cells condense into aligned, densely packed muscle fibers reminiscent of the atrial chamber myocardium (Figure 3B). In this configuration, pacemaker cells display a drop in their ability to rhythmically initiate action potentials and demonstrate a failure to stimulate the adjacent atria (Figure 3C). Retrograde atrial-to pacemaker conduction is preserved, indicating that electrical connections are maintained following proepicardial removal [104]. However, the sinoatrial node cannot activate the larger volume of atrial myocardium to which it was coupled. Of note, the electrophysiological defects observed in hearts following the blocking of embryonic pacemaker cell/fibroblast integration are consistent with computational simulations in which propagation towards increasing electrical load without resistive barriers was conducted $[65,66,125]$, and match closely to the results of Rohr et al. tracking electrical propagation through regions of tissue expansion $[67,126]$. These data suggest that the integration of fibroblasts into the sinoatrial node interstitium is critical for balancing source-sink relationships as cardiac morphogenesis proceeds and the electrical load that downstream myocardial cells place on pacemaker cells becomes untenable. 

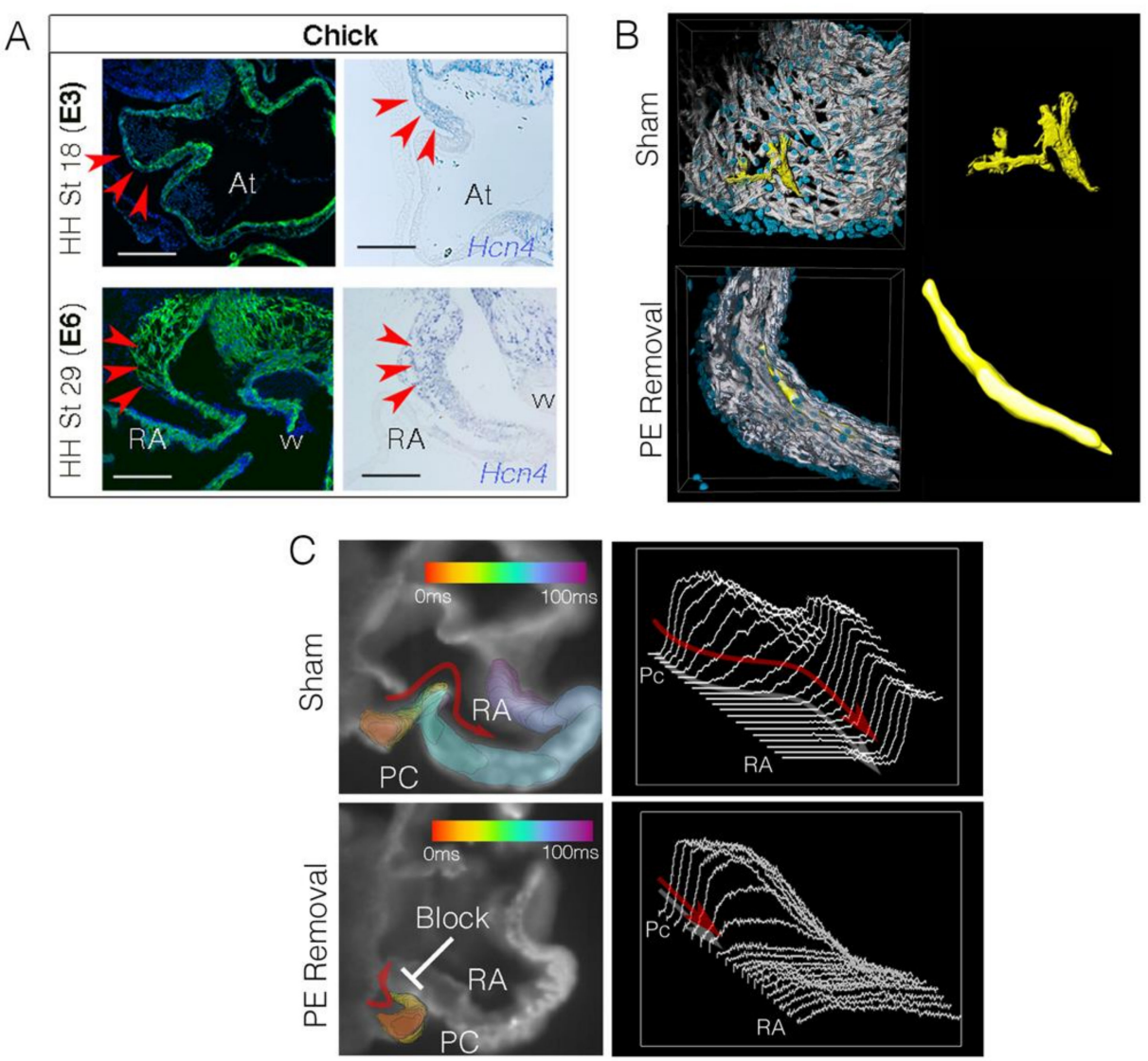

Figure 3. Embryonic remodeling of the sinoatrial node. (A) Sections through the chick sinoatrial node at Hamburger Hamilton (HH) stage 18 [121] equivalent to embryonic day 3 (E3) and HH stage 29 (E6). Sections are stained with muscle marker MF20 (green) and Dapi (blue). In situ hybridization for the pacemaker cell marker Hcn4 indicates the location of the sinoatrial node (red arrowheads) (reproduced from [105]). Scale bar-200 $\mathrm{mm}$. (B) Volumetric reconstructions of the chick sinoatrial node at $\mathrm{HH}$ stage 29. Data are shown from a control embryo (Sham) and an embryo in which proepicardial cells have been blocked from entering the sinoatrial node. MF20-white, Dapi-blue. Groups of pacemaker cells have been reconstructed in yellow to demonstrate the change in morphology when proepicardial cells are prevented from entering the sinoatrial node. (C) Isochronal maps of impulse propagation through sections of the sinoatrial node/atrial junction. Following proepicardial removal, sinoatrial node conduction block occurs (reproduced with permission from [104]). PC-pacemaker cells, RA-right atrium.

In addition to remodeling of the sinoatrial node interstitium, there is a clear heterogeneity in the embryonic sinoatrial node with regard to molecular identity during these stages of development. For instance, the embryonic sinoatrial node has a head region which is positive for the transcription factors Tbx18, Tbx3, Shox2, Isl1 and negative for the transcription factor $N k x 2.5[99,103,113,114]$. These factors set up a transcriptional landscape believed to drive the pacemaker cell genetic program [13,15-17]. Along the tail region of the embryonic sinoatrial node, which serves as a junction to the atrial chamber myocardium, a slightly different genetic program appears to be in place. This region expresses many of the makers of the sinoatrial node head but is also positive for Nkx2.5. By manipulating transcription factor expression directly in this sinoatrial node/atrial junction region, Ye et al. and $\mathrm{Li}$ et al. were able to demonstrate this region is necessary to maintain proper sinoatrial node/atrial electrical interactions [102,127]. As such, the peripheral tail cells along the developing sinoatrial node/atrial interface may represent a transitional cell with phenotypic characteristics in between those of pacemaker cells and atrial myocytes. 


\subsection{Signaling Environment of the Embryonic Sinoatrial Node}

The events that recruit fibroblast-like cell incorporation into the embryonic sinoatrial node, and/or organize the boundaries between the cell types associated with this region of the heart (head, tail, atrial chamber myocardium), are not fully understood. Related to this first point, while it has yet to be experimentally determined how fibroblast-like cells are recruited to the developing sinoatrial node, there is a large amount of data that may allow us to speculate. Indeed, the developmental window in which proepicardial cells invade the forming sinoatrial node has been examined by several groups using nextgeneration sequencing approaches. These studies highlighted a core signaling program in the embryonic sinoatrial node that seems likely to contribute to sinoatrial node morphogenesis. Vedantham et al. used laser capture microscopy followed by RNA sequencing (RNAseq) to compare differentially expressed genes between the embryonic sinoatrial node and atrial myocardium. Among the enriched genes noted in this study were members of the TGFb/BMP paracrine axis and known downstream targets of TGFb and BMP signaling [128]. While it should be noted that several paracrine factors were shown to be enriched in this report, the TGFb/BMP pathway is worth mentioning for several reasons that will be elaborated on below.

In sequencing studies conducted by Liang et al. and Van Eif et al., the enrichment of both upstream and downstream mediators of TGFb/BMP signaling was also demonstrated $[114,129]$. In these studies, sinoatrial node cells were sorted from transgenic animals carrying various fluorescence reporters in the pacemaker cell lineage (Hcn4-CreERT2 Isl1 $1^{\mathrm{f} / \mathrm{fl}}$, or $\mathrm{Tbx}^{+\mathrm{Venus}}$ respectively $\left.[114,129]\right)$, and these cells were processed for bulk RNA sequencing. Indeed, based on their findings, Van Eif et al. directly examined $\mathrm{TGFb} / \mathrm{BMP}$ activity in forming the sinoatrial node and noted nuclear localization of phosoSMAD1/5/8 [129]. This data indicated that TGFb/BMP signaling is active in this region. Furthermore, the Van Eif study confirmed that BMP2 could induce the expression of a subset of pacemaker cell genes. More recent Single-cell RNA sequencing studies by Li et al. and Goodyer et al. further confirmed the enrichment of the TGFb/BMP signaling pathway in the embryonic sinoatrial node myocytes $[127,130]$. In these studies, single cells from the embryonic sinoatrial node (mouse 12.5 and E17.5) were sequenced, allowing for subpopulations to be identified within the heterogeneous cell populations of the sinoatrial node.

The above sequencing studies have spanned a range of embryonic stages from E12.5-E17 in mouse, a developmental window during which proepicardial cells actively integrate with pacemaker myocardium [104]. Significantly, TGFb/BMP pathway enrichment has been noted at earlier time points as well. Examining the transcriptional profile of the forming sinoatrial node just before structural remodeling indicated that BMP2, BMP4, and TGFB2 were all upregulated compared to the atrial myocardium, indicating these factors may contribute to the initial recruitment of proepicardial cells [104]. In adults, these factors are continued to be expressed in the SAN. Linscheid et al. and Brennan et al. noted the persistent enrichment of TGFb/BMP signaling factors in the adult sinoatrial node $[131,132]$. Therefore, the TGFb/BMP signaling is well positioned throughout life to influence sinoatrial node activity.

\subsection{Potential Roles for TGFb/BMP Signaling in Sinoatrial Node Morphogenesis}

While the functional role of BMPs and TGFbs has been extensively studied in the heart and is the subject of several excellent reviews (examples include [133-139]), we highlight some features of this pathway that may suggest their potential function in sinoatrial node morphogenesis.

BMP2/4/6/7, and TGFB1/2 and TGFB receptors2/3 have been identified as upstream factors that induce the morphological process of endocardial cushion formation in the atrioventricular canal and outflow components of the heart [140,141]. Here, a proteoglycan and hyaluronan-rich extracellular matrix termed the cardiac jelly is deposited and maintained in the basement membrane between the endocardium and myocardium (Figure 4A). 
This causes a swelling or separation between endocardial and myocardial layers of the heart that is, at first, acellular but becomes progressively populated by both endocardial and epicardial derived cells [133,142]. The combination of BMPs and TGFBs activates various cellular behaviors during cushion morphogenesis, including ECM deposition and endocardial cell invasion into the cushion structures [137-139]. While no cushions form near the embryonic sinoatrial node (Figure 4B,C), downstream effectors of TGFb/BMP signaling involved in cushion morphogenesis are enriched in several of the above-referenced sinoatrial node sequencing studies (Figure 4E,F) [104,125,126]. This overlap may suggest a process analogous to cushion formation is occurring during sinoatrial node formation. However, instead of generating an acellular cardiac jelly, it results in the remodeling of the pacemaker interstitium and transitioning this region into the patchy myocardium alluded to above.

The second point worth discussing relates to the known roles of $\mathrm{TGFb} / \mathrm{BMP}$ in directing proepicardial derived cell behavior. Ishii et al. demonstrated that primary proepicardial cells would orient their axis of migration specifically towards sources of BMP2/4. While this study was focused on the paracrine factors that induce proepicardial outgrowth towards the embryonic atrioventricular junction, the shared enrichment of BMP2/ 4 in the forming sinoatrial node would highlight these factors as potential drivers of proepicardial cell recruitment into the pacemaking region of the heart [143]. Hill et al. further showed that BMP2 treatment results in loss of epithelial character and decreased cellcell adhesion in an immortalized epicardial cell line [144]. These studies indicated that the expression of BMP2/4 by pacemaker cells would prime adjacent proepicardial/epicardial cells towards an invasive phenotype. Furthermore, Craig et al. demonstrated that TGFB2 is known to induce Hyaluronan synthase 2 (Has2) expression in epicardial cells [145]. High molecular weight hyaluronan, combined with TGFB2, stimulates epicardial cell epithelial-to-mesenchymal transition (EMT) and cellular invasion. Of note, the remodeling embryonic sinoatrial node displays high interstitial HA levels (Figure 4B,C), and Has2 is elevated in several of the reported sequencing studies referenced above $[104,128]$. Thus, the paracrine microenvironment that emerges during sinoatrial node development does appear consistent with epicardial cell recruitment and invasion. Additionally, among the factors that BMP2/4 activated in the epicardial cells is elastin (ELN) [146]. This is of particular note as the elastic nature of the sinoatrial node extracellular matrix has been noted by several groups, and ELN is deposited at high levels in the interstitial spaces of the mature sinoatrial node $[131,147,148]$.

Finally, there is a complex interplay between TGFbs and BMPs during the process of myofibroblasts activation. TGFbs (typically TGFb1) are generally associated with the fibroblast-to myofibroblast transition that often occurs during wound healing and repair. During these processes, fibroblasts upregulate alpha-smooth muscle actin, become proliferative, and take on a contractile/synthetic phenotype in which they produce high levels of collagens, fibronectin and matrix metalloproteinases [152-154]. As a result, activated myofibroblasts are primed to generate and remodel extracellular microenvironments. However, it should be noted that BMP signaling appears to dampen or attenuate TGFb-mediated fibrotic remodeling in the heart [155-157]. Thus, how these signaling pathways interact during sinoatrial node morphogenesis requires further exploration. 

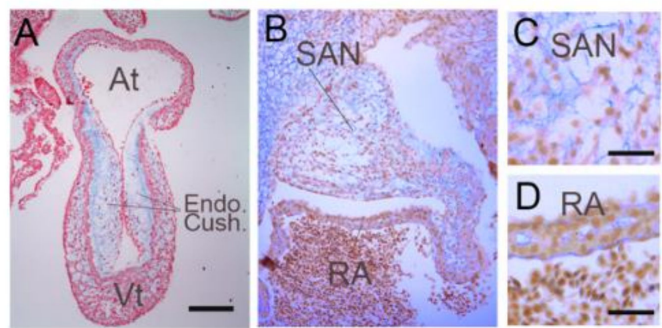

$\mathrm{E}$

Endocardial Cushion Gene regulatrory Network

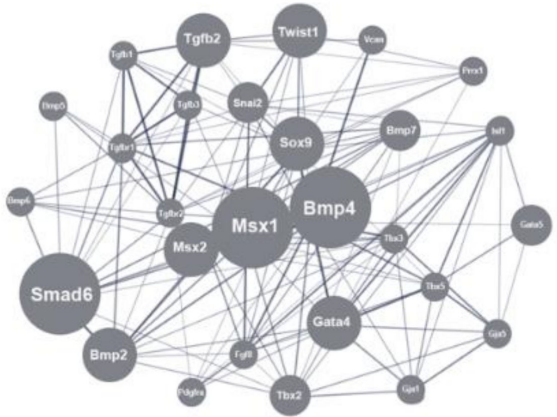

F

Common SAN and Cushion Enriched Genes

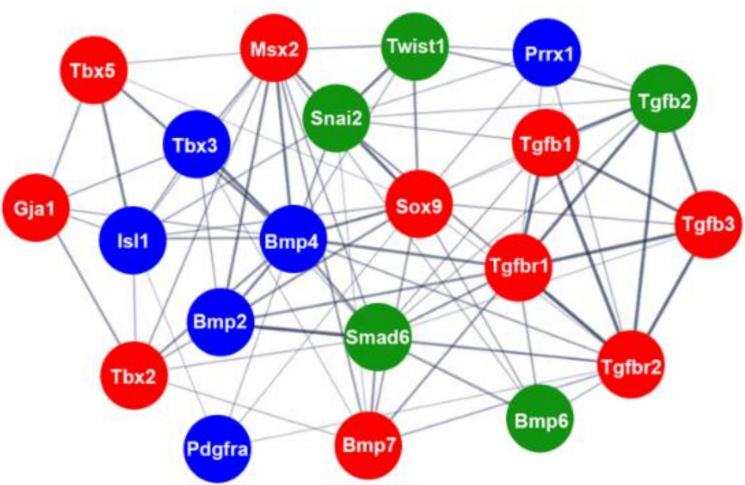

Figure 4. Genetic pathways active during sinoatrial node remodeling. (A) Sagittal section through an $\mathrm{HH}$ stage 19 chick heart stained with alcian blue (blue) which labels HA and nuclear fast red (red). Endocardial cushions are indicated. Scale bare-500 mm. (B) Section through the remodeling sinoatrial node of a chick embryo at HH stage 29. Sinoatrial node (SAN) and right atrium (RA are indicated). (C,D) Higher magnification images from (B). Scale Bars-50 mm. (E) Genes list was generated by comparing the Gene Ontology (GO) term Endocardial Cushion Development (0003197) with the gene regulatory networks published by DeLaughter et al. [149] and enriched genes from Schroeder et al. [150] and Singh et al. [151]. Node size reflects the number of data sets in which the indicated gene is present. Line thickness denotes confidence of potential interaction between genes [152]. (F) Comparison of genes identified as upregulated in the sinoatrial node based on sequencing studies from Vedantham et al., Bressan et al., and Van Eif et al. [104,128,129] Genes with greater than two-fold enrichment over atrial myocardium in all three data sets were compared to the gene-regulatory network for cushion formation in (D). Genes in blue nodes were enriched in all three RNA sequencing data sets, green nodes were present in two data sets, red nodes were detected in one data set.

\section{Conclusions and Future Perspectives}

Sinoatrial node dysfunction represents a significant clinical burden in the US, accounting for the surgical implantation of 200,000 pacing devices each year [158] and over one million pacing devices worldwide [159]. Due to challenges associated with the implantation of pacing devices (particularly in young patients), the creation of tissue- 
engineered pacemaker cells to combat arrhythmic diseases has gained general interest over the past 20 years $[17,160-167]$. Significant effort is now being placed on exploring cellular-based therapeutics for correcting cardiac pacemaker cell dysfunction. However, the design and implementation of the next generation of cellular therapeutics will require a detailed understanding of the functional roles of all of the cell types in the sinoatrial node as well as an appreciation of the electronic interactions that govern sinoatrial node function. Here, we have described the physiological barriers pacemaker cells face, the mechanisms by which these barriers may be overcome, and the developmental events that lead to the construction of a competent sinoatrial node. Big questions remain, mainly related to applying theoretical understandings of pacemaker cell activity to the cellular and molecular regulators of sinoatrial node architecture. For instance, how does sinoatrial node developmental morphogenesis influence the parameters that dictate synchronization and what direct roles do BMPs and TGFbs play in sinoatrial node patterning?

Addressing this intersection between tissue-level sinoatrial node structure and function is of significant clinical interest, to establish a framework through which the vulnerabilities leading to pacemaker dysfunction can be viewed. Moreover, developing a holistic model of sinoatrial node electro-anatomy can provide a template on which future cellular-based therapeutics can be built. Herein, examining the process of sinoatrial node self-assembly during embryonic development can serve as a foundational resource for advancing our basic scientific and clinical understanding of cardiac pacemaking and inspire the next generation of interventional approaches.

Author Contributions: M.E., S.R., A.J.M. and M.B. contributed to the drafting, review, editing, and construction of visuals for this manuscript. S.R. and M.B. were responsible for acquiring funding support for this work. All authors have read and agreed to the published version of the manuscript.

Funding: This work was supported by National Institutes of Health grant R01HL146626 (NHLBI) to M.B., and American Heart Association grants 19POST34380213 to R.S. and 19CDA34760248 to M.B.

Acknowledgments: We would like to thank Julie Goudy and Trevor Henley for their reading and comments on the manuscript.

Conflicts of Interest: The authors declare no conflict of interests in the decision to publish this work.

\section{References}

1. Bouman, L.N.; Jongsma, H.J. Structure and function of the sino-atrial node: A review. Eur. Heart J. 1986, 7, 94-104. [CrossRef] [PubMed]

2. Keith, A.; Flack, M. The Form and Nature of the Muscular Connections between the Primary Divisions of the Vertebrate Heart. J. Anat. Physiol. 1907, 41, 172-189. [PubMed]

3. Hirschhorn, R. Adenosine deaminase deficiency. Immunodefic. Rev. 1990, 2, 175-198. [CrossRef] [PubMed]

4. Tiwari, R.; Kumar, R.; Malik, S.; Raj, T.; Kumar, P. Analysis of Heart rate Variability and Implication of Different Factors on Heart Rate Variability. Curr. Cardiol. Rev. 2020. [CrossRef]

5. Jensen, P.N.; Gronroos, N.N.; Chen, L.Y.; Folsom, A.R.; de Filippi, C.; Heckbert, S.R.; Alonso, A. Incidence of and risk factors for sick sinus syndrome in the general population. J. Am. Coll Cardiol 2014, 64, 531-538. [CrossRef]

6. Mann, D.L.; Zipes, D.P.; Libby, P.; Bonow, R.O.; Braunwald, E. Braunwald's Heart Disease: A Textbook of Cardiovascular Medicine, 10th ed.; Elsevier/Saunders: Philadelphia, PA, USA, 2015.

7. Kusumoto, F.M.; Schoenfeld, M.H.; Barrett, C.; Edgerton, J.R.; Ellenbogen, K.A.; Gold, M.R.; Goldschlager, N.F.; Hamilton, R.M.; Joglar, J.A.; Kim, R.J.; et al. 2018 ACC/AHA/HRS Guideline on the Evaluation and Management of Patients with Bradycardia and Cardiac Conduction Delay: A Report of the American College of Cardiology/American Heart Association Task Force on Clinical Practice Guidelines and the Heart Rhythm Society. Circulation 2019, 140, e382-e482. [CrossRef]

8. Lakatta, E.G.; Maltsev, V.A.; Vinogradova, T.M. A coupled SYSTEM of intracellular $\mathrm{Ca}^{2+}$ clocks and surface membrane voltage clocks controls the timekeeping mechanism of the heart's pacemaker. Circ. Res. 2010, 106, 659-673. [CrossRef]

9. Maltsev, V.A.; Lakatta, E.G. The funny current in the context of the coupled-clock pacemaker cell system. Heart Rhythm 2012, 9, 302-307. [CrossRef]

10. Yaniv, Y.; Lakatta, E.G.; Maltsev, V.A. From two competing oscillators to one coupled-clock pacemaker cell system. Front. Physiol. 2015, 6, 28. [CrossRef]

11. Joyner, R.W.; Wilders, R.; Wagner, M.B. Propagation of pacemaker activity. Med. Biol Eng. Comput 2007, 45, 177-187. [CrossRef]

12. Li, P.; Lines, G.; Maleckar, M.; Tveito, A. Mathematical models of cardiac pacemaking function. Front. Phys. 2013, 1. [CrossRef] 
13. Ye, W.; Song, Y.; Huang, Z.; Zhang, Y.; Chen, Y. Genetic Regulation of Sinoatrial Node Development and Pacemaker Program in the Venous Pole. J. Cardiovasc Dev. Dis 2015, 2, 282-298. [CrossRef]

14. Mommersteeg, M.T.; Hoogaars, W.M.; Prall, O.W.; de Gier-de Vries, C.; Wiese, C.; Clout, D.E.; Papaioannou, V.E.; Brown, N.A.; Harvey, R.P.; Moorman, A.F.; et al. Molecular pathway for the localized formation of the sinoatrial node. Circ. Res. 2007, 100, 354-362. [CrossRef]

15. Van Eif, V.W.W.; Devalla, H.D.; Boink, G.J.J.; Christoffels, V.M. Transcriptional regulation of the cardiac conduction system. Nat. Rev. Cardiol 2018, 15, 617-630. [CrossRef]

16. Liang, X.; Evans, S.M.; Sun, Y. Development of the cardiac pacemaker. Cell Mol. Life Sci. 2017, 74, 1247-1259. [CrossRef]

17. Vedantham, V. New Approaches to Biological Pacemakers: Links to Sinoatrial Node Development. Trends Mol. Med. 2015, 21, 749-761. [CrossRef]

18. Adler, C.P.; Costabel, U. Cell number in human heart in atrophy, hypertrophy, and under the influence of cytostatics. Recent Adv. Stud. Card. Struct. Metab. 1975, 6, 343-355.

19. Herget, G.W.; Neuburger, M.; Plagwitz, R.; Adler, C.P. DNA content, ploidy level and number of nuclei in the human heart after myocardial infarction. Cardiovasc. Res. 1997, 36, 45-51. [CrossRef]

20. Kleber, A.G.; Rudy, Y. Basic mechanisms of cardiac impulse propagation and associated arrhythmias. Physiol. Rev. 2004, 84, 431-488. [CrossRef]

21. Issa, Z.F.; Miller, J.M.; Zipes, D.P. Molecular Mechanisms of Cardiac Electrical Activity. In Clinical Arrhythmology and Electrophysiology, 3rd ed.; Issa, Z.F., Miller, J.M., Zipes, D.P., Eds.; Elsevier: Philadelphia, PA, USA, 2019; pp. 1-14. [CrossRef]

22. Kleber, A.G. Gap junctions and conduction of cardiac excitation. Heart Rhythm 2011, 8, 1981-1984. [CrossRef]

23. Unudurthi, S.D.; Wolf, R.M.; Hund, T.J. Role of sinoatrial node architecture in maintaining a balanced source-sink relationship and synchronous cardiac pacemaking. Front. Physiol. 2014, 5, 446. [CrossRef]

24. Joyner, R.W.; van Capelle, F.J. Propagation through electrically coupled cells. How a small SA node drives a large atrium. Biophys J. 1986, 50, 1157-1164. [CrossRef]

25. Bottani, S. Pulse-coupled relaxation oscillators: From biological synchronization to self-organized criticality. Phys. Rev. Lett 1995, 74, 4189-4192. [CrossRef]

26. Winfree, A.T. Biological rhythms and the behavior of populations of coupled oscillators. J. Biol. 1967, 16, 15-42. [CrossRef]

27. Mirollo, R.E.; Strogatz, S.H. Synchronization of Pulse-Coupled Biological Oscillators. Siam J. Appl. Math. 1990, 50, 1645-1662. [CrossRef]

28. Glass, L. Synchronization and rhythmic processes in physiology. Nature 2001, 410, 277-284. [CrossRef]

29. Monfredi, O.; Tsutsui, K.; Ziman, B.; Stern, M.D.; Lakatta, E.G.; Maltsev, V.A. Electrophysiological heterogeneity of pacemaker cells in the rabbit intercaval region, including the SA node: Insights from recording multiple ion currents in each cell. Am. J. Physiol. Heart Circ. Physiol. 2018, 314, H403-H414. [CrossRef]

30. Kim, M.S.; Maltsev, A.V.; Monfredi, O.; Maltseva, L.A.; Wirth, A.; Florio, M.C.; Tsutsui, K.; Riordon, D.R.; Parsons, S.P.; Tagirova, S.; et al. Heterogeneity of calcium clock functions in dormant, dysrhythmically and rhythmically firing single pacemaker cells isolated from SA node. Cell Calcium. 2018, 74, 168-179. [CrossRef]

31. Wilders, R.; Jongsma, H.J. Beating irregularity of single pacemaker cells isolated from the rabbit sinoatrial node. Biophys. J. 1993, 65, 2601-2613. [CrossRef]

32. Lyashkov, A.E.; Juhaszova, M.; Dobrzynski, H.; Vinogradova, T.M.; Maltsev, V.A.; Juhasz, O.; Spurgeon, H.A.; Sollott, S.J.; Lakatta, E.G. Calcium Cycling Protein Density and Functional Importance to Automaticity of Isolated Sinoatrial Nodal Cells Are Independent of Cell Size. Circ. Res. 2007, 100, 1723-1731. [CrossRef]

33. Bleeker, W.K.; Mackaay, A.J.; Masson-Pevet, M.; Bouman, L.N.; Becker, A.E. Functional and morphological organization of the rabbit sinus node. Circ. Res. 1980, 46, 11-22. [CrossRef] [PubMed]

34. Clay, J.R.; DeHaan, R.L. Fluctuations in interbeat interval in rhythmic heart-cell clusters. Role of membrane voltage noise. Biophys. J. 1979, 28, 377-389. [CrossRef]

35. Rodrigues, F.A.; Peron, T.K.D.; Ji, P.; Kurths, J. The Kuramoto model in complex networks. Phys. Rep. 2016, 610, 1-98. [CrossRef]

36. Kuramoto, Y. Mutual Entrainment. In Chemical Oscillations, Waves, and Turbulence; Springer: Berlin/Heidelberg, Germany, 1984; pp. 60-88. [CrossRef]

37. Jalife, J. Mutual entrainment and electrical coupling as mechanisms for synchronous firing of rabbit sino-atrial pace-maker cells. J. Physiol. 1984, 356, 221-243. [CrossRef]

38. Anumonwo, J.M.; Delmar, M.; Vinet, A.; Michaels, D.C.; Jalife, J. Phase resetting and entrainment of pacemaker activity in single sinus nodal cells. Circ. Res. 1991, 68, 1138-1153. [CrossRef]

39. Verheijck, E.E.; Wilders, R.; Joyner, R.W.; Golod, D.A.; Kumar, R.; Jongsma, H.J.; Bouman, L.N.; van Ginneken, A.C. Pacemaker synchronization of electrically coupled rabbit sinoatrial node cells. J. Gen. Physiol. 1998, 111, 95-112. [CrossRef]

40. Cai, D.; Winslow, R.L.; Noble, D. Effects of gap junction conductance on dynamics of sinoatrial node cells: Two-cell and large-scale network models. IEEE Trans. Biomed. Eng. 1994, 41, 217-231. [CrossRef]

41. Van Meerwijk, W.P.; de Bruin, G.; Van Ginneken, C.G.; Van Hartevelt, J.; Jongsma, H.J.; Kruyt, E.W.; Scott, S.S.; Ypey, D.L. Phase resetting properties of cardiac pacemaker cells. J. Gen. Physiol. 1984, 83, 613-629. [CrossRef]

42. Michaels, D.C.; Matyas, E.P.; Jalife, J. Dynamic interactions and mutual synchronization of sinoatrial node pacemaker cells. A mathematical model. Circ. Res. 1986, 58, 706-720. [CrossRef] 
43. Nicolás Mata, A.; Román Alonso, G.; López Garza, G.; Godinez Fernández, J.R.; Castro García, M.A.; Castellanos Ábrego, N.P. Parallel simulation of the synchronization of heterogeneous cells in the sinoatrial node. Concurr. Comput. Pract. Exp. 2020, 32, e5317. [CrossRef]

44. Michaels, D.C.; Matyas, E.P.; Jalife, J. Mechanisms of sinoatrial pacemaker synchronization: A new hypothesis. Circ. Res. 1987, 61, 704-714. [CrossRef]

45. Gratz, D.; Onal, B.; Dalic, A.; Hund, T.J. Synchronization of Pacemaking in the Sinoatrial Node: A Mathematical Modeling Study. Front. Phys. 2018, 6. [CrossRef]

46. Ly, C.; Weinberg, S.H. Analysis of heterogeneous cardiac pacemaker tissue models and traveling wave dynamics. J. Biol. 2018, 459, 18-35. [CrossRef]

47. Karpaev, A.A.; Syunyaev, R.A.; Aliev, R.R. Effects of fibroblast-myocyte coupling on the sinoatrial node activity: A computational study. Int. J. Numer. Method Biomed. Eng. 2018, 34, e2966. [CrossRef]

48. Sehgal, S.; Patel, N.D.; Malik, A.; Roop, P.S.; Trew, M.L. Resonant model-A new paradigm for modeling an action potential of biological cells. PLoS ONE 2019, 14, e0216999. [CrossRef]

49. Opthof, T. The mammalian sinoatrial node. Cardiovasc. Drugs Ther. 1988, 1, 573-597. [CrossRef]

50. Lev, M. Aging changes in the human sinoatrial node. J. Gerontol. 1954, 9, 1-9. [CrossRef]

51. James, T.N. Anatomy of the human sinus node. Anat. Rec. 1961, 141, 109-139. [CrossRef]

52. Truex, R.C.; Smythe, M.Q.; Taylor, M.J. Reconstruction of the human sinoatrial node. Anat. Rec. 1967, 159, 371-378. [CrossRef]

53. Hao, X.; Zhang, Y.; Zhang, X.; Nirmalan, M.; Davies, L.; Konstantinou, D.; Yin, F.; Dobrzynski, H.; Wang, X.; Grace, A.; et al. TGF- $\beta 1$-mediated fibrosis and ion channel remodeling are key mechanisms in producing the sinus node dysfunction associated with SCN5A deficiency and aging. Circ. Arrhythm. Electrophysiol. 2011, 4, 397-406. [CrossRef]

54. Glukhov, A.V.; Kalyanasundaram, A.; Lou, Q.; Hage, L.T.; Hansen, B.J.; Belevych, A.E.; Mohler, P.J.; Knollmann, B.C.; Periasamy, M.; Györke, S.; et al. Calsequestrin 2 deletion causes sinoatrial node dysfunction and atrial arrhythmias associated with altered sarcoplasmic reticulum calcium cycling and degenerative fibrosis within the mouse atrial pacemaker complex1. Eur. Heart J. 2015, 36, 686-697. [CrossRef] [PubMed]

55. Opthof, T.; de Jonge, B.; Masson-Pevet, M.; Jongsma, H.J.; Bouman, L.N. Functional and morphological organization of the cat sinoatrial node. J. Mol. Cell. Cardiol. 1986, 18, 1015-1031. [CrossRef]

56. Shiraishi, I.; Takamatsu, T.; Minamikawa, T.; Onouchi, Z.; Fujita, S. Quantitative histological analysis of the human sinoatrial node during growth and aging. Circulation 1992, 85, 2176-2184. [CrossRef] [PubMed]

57. Kohl, P.; Kamkin, A.G.; Kiseleva, I.S.; Noble, D. Mechanosensitive fibroblasts in the sino-atrial node region of rat heart: Interaction with cardiomyocytes and possible role. Exp. Physiol. 1994, 79, 943-956. [CrossRef]

58. Oren, R.V.; Clancy, C.E. Determinants of heterogeneity, excitation and conduction in the sinoatrial node: A model study. PLoS Comput. Biol. 2010, 6, e1001041. [CrossRef]

59. Miragoli, M.; Gaudesius, G.; Rohr, S. Electrotonic modulation of cardiac impulse conduction by myofibroblasts. Circ. Res. 2006, 98, 801-810. [CrossRef]

60. Fahrenbach, J.P.; Mejia-Alvarez, R.; Banach, K. The relevance of non-excitable cells for cardiac pacemaker function. J. Physiol. 2007, 585, 565-578. [CrossRef]

61. Miragoli, M.; Salvarani, N.; Rohr, S. Myofibroblasts induce ectopic activity in cardiac tissue. Circ. Res. 2007, 101, 755-758. [CrossRef]

62. Camelliti, P. Fibroblast Network in Rabbit Sinoatrial Node: Structural and Functional Identification of Homogeneous and Heterogeneous Cell Coupling. Circ. Res. 2004, 94, 828-835. [CrossRef]

63. Gaudesius, G.; Miragoli, M.; Thomas, S.P.; Rohr, S. Coupling of cardiac electrical activity over extended distances by fibroblasts of cardiac origin. Circ. Res. 2003, 93, 421-428. [CrossRef]

64. De Mazière, A.M.G.L.; van Ginneken, A.C.G.; Wilders, R.; Jongsma, H.J.; Bouman, L.N. Spatial and functional relationship between myocytes and fibroblasts in the rabbit sinoatrial node. J. Mol. Cell. Cardiol. 1992, 24, 567-578. [CrossRef]

65. Joyner, R.W.; Veenstra, R.; Rawling, D.; Chorro, A. Propagation through electrically coupled cells. Effects of a resistive barrier. Biophys. J. 1984, 45, 1017-1025. [CrossRef]

66. Joyner, R.W. Effects of the discrete pattern of electrical coupling on propagation through an electrical syncytium. Circ. Res. 1982, 50, 192-200. [CrossRef]

67. Rohr, S.; Kucera, J.P.; Fast, V.G.; Kleber, A.G. Paradoxical improvement of impulse conduction in cardiac tissue by partial cellular uncoupling. Science 1997, 275, 841-844. [CrossRef]

68. Huang, X.; Cui, X. The Functions of Atrial Strands Interdigitating with and Penetrating into Sinoatrial Node: A Theoretical Study of the Problem. PLoS ONE 2015, 10, e0118623. [CrossRef]

69. Anumonwo, J.M.; Wang, H.Z.; Trabka-Janik, E.; Dunham, B.; Veenstra, R.D.; Delmar, M.; Jalife, J. Gap junctional channels in adult mammalian sinus nodal cells. Immunolocalization and electrophysiology. Circ. Res. 1992, 71, 229-239. [CrossRef]

70. Verheule, S.; van Batenburg, C.A.; Coenjaerts, F.E.; Kirchhoff, S.; Willecke, K.; Jongsma, H.J. Cardiac conduction abnormalities in mice lacking the gap junction protein connexin40. J. Cardiovasc. Electrophysiol. 1999, 10, 1380-1389. [CrossRef]

71. Boyett, M.R.; Honjo, H.; Kodama, I. The sinoatrial node, a heterogeneous pacemaker structure. Cardiovasc. Res. 2000, 47, 658-687. [CrossRef] 
72. Verheule, S.; van Kempen, M.J.; te Welscher, P.H.; Kwak, B.R.; Jongsma, H.J. Characterization of gap junction channels in adult rabbit atrial and ventricular myocardium. Circ. Res. 1997, 80, 673-681. [CrossRef]

73. Jongsma, H.J.; Wilders, R. Gap Junctions in Cardiovascular Disease. Circ. Res. 2000, 86, 1193-1197. [CrossRef]

74. Ten Velde, I.; de Jonge, B.; Verheijck, E.E.; van Kempen, M.J.; Analbers, L.; Gros, D.; Jongsma, H.J. Spatial distribution of connexin43, the major cardiac gap junction protein, visualizes the cellular network for impulse propagation from sinoatrial node to atrium. Circ. Res. 1995, 76, 802-811. [CrossRef]

75. Lovell, N.H.; Cloherty, S.L.; Celler, B.G.; Dokos, S. A gradient model of cardiac pacemaker myocytes. Prog. Biophys. Mol. Biol. 2004, 85, 301-323. [CrossRef]

76. Inada, S.; Zhang, H.; Tellez, J.O.; Shibata, N.; Nakazawa, K.; Kamiya, K.; Kodama, I.; Mitsui, K.; Dobrzynski, H.; Boyett, M.R.; et al. Importance of gradients in membrane properties and electrical coupling in sinoatrial node pacing. PLoS ONE 2014, 9, e94565. [CrossRef]

77. Zhang, H.; Holden, A.V.; Boyett, M.R. Gradient model versus mosaic model of the sinoatrial node. Circulation 2001, 103, 584-588. [CrossRef]

78. López Garza, G.; Castellanos, N.P.; Godínez, R. Cell-to-cell modeling of the interface between atrial and sinoatrial anisotropic heterogeneous nets. Comput. Biol. Chem. 2017, 68, 245-259. [CrossRef]

79. Bromberg, B.I.; Hand, D.E.; Schuessler, R.B.; Boineau, J.P. Primary negativity does not predict dominant pacemaker location: Implications for sinoatrial conduction. Am. J. Physiol. 1995, 269, H877-H887. [CrossRef]

80. Schuessler, R.B. Abnormal sinus node function in clinical arrhythmias. J. Cardiovasc. Electrophysiol. 2003, 14, 215-217. [CrossRef] [PubMed]

81. Fedorov, V.V.; Glukhov, A.V.; Chang, R.; Kostecki, G.; Aferol, H.; Hucker, W.J.; Wuskell, J.P.; Loew, L.M.; Schuessler, R.B.; Moazami, N.; et al. Optical mapping of the isolated coronary-perfused human sinus node. J. Am. Coll. Cardiol. 2010, 56, 1386-1394. [CrossRef] [PubMed]

82. Fedorov, V.V.; Schuessler, R.B.; Hemphill, M.; Ambrosi, C.M.; Chang, R.; Voloshina, A.S.; Brown, K.; Hucker, W.J.; Efimov, I.R. Structural and functional evidence for discrete exit pathways that connect the canine sinoatrial node and atria. Circ. Res. 2009, 104, 915-923. [CrossRef] [PubMed]

83. Kalyanasundaram, A.; Li, N.; Hansen, B.J.; Zhao, J.; Fedorov, V.V. Canine and human sinoatrial node: Differences and similarities in the structure, function, molecular profiles, and arrhythmia. J. Vet. Cardiol. 2019, 22, 2-19. [CrossRef] [PubMed]

84. Csepe, T.A.; Zhao, J.; Hansen, B.J.; Li, N.; Sul, L.V.; Lim, P.; Wang, Y.; Simonetti, O.P.; Kilic, A.; Mohler, P.J.; et al. Human sinoatrial node structure: 3D microanatomy of sinoatrial conduction pathways. Prog. Biophys. Mol. Biol. 2016, 120, 164-178. [CrossRef]

85. Li, N.; Hansen, B.J.; Csepe, T.A.; Zhao, J.; Ignozzi, A.J.; Sul, L.V.; Zakharkin, S.O.; Kalyanasundaram, A.; Davis, J.P.; Biesiadecki, B.J.; et al. Redundant and diverse intranodal pacemakers and conduction pathways protect the human sinoatrial node from failure. Sci. Transl. Med. 2017, 9. [CrossRef]

86. Lou, Q.; Hansen, B.J.; Fedorenko, O.; Csepe, T.A.; Kalyanasundaram, A.; Li, N.; Hage, L.T.; Glukhov, A.V.; Billman, G.E.; Weiss, R.; et al. Upregulation of adenosine A1 receptors facilitates sinoatrial node dysfunction in chronic canine heart failure by exacerbating nodal conduction abnormalities revealed by novel dual-sided intramural optical mapping. Circulation 2014, 130, 315-324. [CrossRef]

87. Ho, S.Y.; Sánchez-Quintana, D. Anatomy and pathology of the sinus node. J. Interv. Card. Electrophysiol. 2016, 46, 3-8. [CrossRef]

88. Chandler, N.J.; Greener, I.D.; Tellez, J.O.; Inada, S.; Musa, H.; Molenaar, P.; Difrancesco, D.; Baruscotti, M.; Longhi, R.; Anderson, R.H.; et al. Molecular architecture of the human sinus node: Insights into the function of the cardiac pacemaker. Circulation 2009, 119, 1562-1575. [CrossRef]

89. Sánchez-Quintana, D.; Cabrera, J.A.; Farré, J.; Climent, V.; Anderson, R.H.; Ho, S.Y. Sinus node revisited in the era of electroanatomical mapping and catheter ablation. Heart 2005, 91, 189-194. [CrossRef]

90. Matsuyama, T.-A.; Inoue, S.; Kobayashi, Y.; Sakai, T.; Saito, T.; Katagiri, T.; Ota, H. Anatomical diversity and age-related histological changes in the human right atrial posterolateral wall. EP Eur. 2004, 6, 307-315. [CrossRef]

91. Monfredi, O.; Dobrzynski, H.; Mondal, T.; Boyett, M.R.; Morris, G.M. The anatomy and physiology of the sinoatrial node-A contemporary review. Pacing Clin. Electrophysiol. 2010, 33, 1392-1406. [CrossRef]

92. Kharche, S.R.; Vigmond, E.; Efimov, I.R.; Dobrzynski, H. Computational assessment of the functional role of sinoatrial node exit pathways in the human heart. PLoS ONE 2017, 12, e0183727. [CrossRef]

93. Kamino, K.; Hirota, A.; Fujii, S. Localization of pacemaking activity in early embryonic heart monitored using voltage-sensitive dye. Nature 1981, 290, 595-597. [CrossRef]

94. Van Mierop, L.H. Location of pacemaker in chick embryo heart at the time of initiation of heartbeat. Am. J. Physiol. 1967, 212, 407-415. [CrossRef]

95. Bressan, M.; Liu, G.; Mikawa, T. Early mesodermal cues assign avian cardiac pacemaker fate potential in a tertiary heart field. Science 2013, 340, 744-748. [CrossRef] [PubMed]

96. Patten, B.M. Initiation and early changes in the character of the heart beat in vertebrate embryos. Physiol. Rev. 1949, 29, 31-47. [CrossRef]

97. Mommersteeg, M.T.; Dominguez, J.N.; Wiese, C.; Norden, J.; de Gier-de Vries, C.; Burch, J.B.; Kispert, A.; Brown, N.A.; Moorman, A.F.; Christoffels, V.M. The sinus venosus progenitors separate and diversify from the first and second heart fields early in development. Cardiovasc. Res. 2010, 87, 92-101. [CrossRef] 
98. Dominguez, J.N.; Meilhac, S.M.; Bland, Y.S.; Buckingham, M.E.; Brown, N.A. Asymmetric fate of the posterior part of the second heart field results in unexpected left/right contributions to both poles of the heart. Circ. Res. 2012, 111, 1323-1335. [CrossRef]

99. Wiese, C.; Grieskamp, T.; Airik, R.; Mommersteeg, M.T.; Gardiwal, A.; de Gier-de Vries, C.; Schuster-Gossler, K.; Moorman, A.F.; Kispert, A.; Christoffels, V.M. Formation of the sinus node head and differentiation of sinus node myocardium are independently regulated by Tbx18 and Tbx3. Circ. Res. 2009, 104, 388-397. [CrossRef]

100. Hoogaars, W.M.; Engel, A.; Brons, J.F.; Verkerk, A.O.; de Lange, F.J.; Wong, L.Y.; Bakker, M.L.; Clout, D.E.; Wakker, V.; Barnett, P.; et al. Tbx3 controls the sinoatrial node gene program and imposes pacemaker function on the atria. Genes Dev. 2007, 21, 1098-1112. [CrossRef]

101. Blaschke, R.J.; Hahurij, N.D.; Kuijper, S.; Just, S.; Wisse, L.J.; Deissler, K.; Maxelon, T.; Anastassiadis, K.; Spitzer, J.; Hardt, S.E.; et al. Targeted mutation reveals essential functions of the homeodomain transcription factor Shox 2 in sinoatrial and pacemaking development. Circulation 2007, 115, 1830-1838. [CrossRef]

102. Ye, W.; Wang, J.; Song, Y.; Yu, D.; Sun, C.; Liu, C.; Chen, F.; Zhang, Y.; Wang, F.; Harvey, R.P.; et al. A common Shox2-Nkx2-5 antagonistic mechanism primes the pacemaker cell fate in the pulmonary vein myocardium and sinoatrial node. Development 2015, 142, 2521-2532. [CrossRef]

103. Espinoza-Lewis, R.A.; Yu, L.; He, F.; Liu, H.; Tang, R.; Shi, J.; Sun, X.; Martin, J.F.; Wang, D.; Yang, J.; et al. Shox2 is essential for the differentiation of cardiac pacemaker cells by repressing Nkx2-5. Dev. Biol. 2009, 327, 376-385. [CrossRef]

104. Bressan, M.; Henley, T.; Louie, J.D.; Liu, G.; Christodoulou, D.; Bai, X.; Taylor, J.; Seidman, C.E.; Seidman, J.G.; Mikawa, T. Dynamic Cellular Integration Drives Functional Assembly of the Heart's Pacemaker Complex. CELREP 2018, 23, $2283-2291$. [CrossRef] [PubMed]

105. Vicente-Steijn, R.; Kolditz, D.P.; Mahtab, E.A.F.; Askar, S.F.A.; Bax, N.A.M.; van der Graaf, L.M.; Wisse, L.J.; Passier, R.; Pijnappels, D.A.; Schalij, M.J.; et al. Electrical Activation of Sinus Venosus Myocardium and Expression Patterns of RhoA and Isl-1 in the Chick Embryo. J. Cardiovasc. Electrophysiol. 2010, 21, 1284-1292. [CrossRef] [PubMed]

106. Vicente-Steijn, R.; Passier, R.; Wisse, L.J.; Schalij, M.J.; Poelmann, R.E.; Gittenberger-de Groot, A.C.; Jongbloed, M.R. Funny current channel HCN4 delineates the developing cardiac conduction system in chicken heart. Heart Rhythm 2011, 8, 1254-1263. [CrossRef] [PubMed]

107. Lieberman, M.; Paes de Carvalho, A. The Electrophysiological Organization of the Embryonic Chick Heart. J. Gen. Physiol. 1965, 49, 351-363. [CrossRef]

108. Sperelakis, N.; Shigenobu, K. Changes in membrane properties of chick embryonic hearts during development. J. Gen. Physiol. 1972, 60, 430-453. [CrossRef]

109. Bressan, M.; Yang, P.B.; Louie, J.D.; Navetta, A.M.; Garriock, R.J.; Mikawa, T. Reciprocal myocardial-endocardial interactions pattern the delay in atrioventricular junction conduction. Development 2014, 141, 4149-4157. [CrossRef]

110. Williams, E.H.; DeHaan, R.L. Electrical coupling among heart cells in the absence of ultrastructurally defined gap junctions. J. Membr. Biol. 1981, 60, 237-248. [CrossRef]

111. Gros, D.; Mocquard, J.P.; Challice, C.E.; Schrevel, J. Formation and growth of gap junctions in mouse myocardium during ontogenesis: Quantitative data and their implications on the development of intercellular communication. J. Mol. Cell. Cardiol. 1979, 11, 543-554. [CrossRef]

112. Christoffels, V.M.; Mommersteeg, M.T.; Trowe, M.O.; Prall, O.W.; de Gier-de Vries, C.; Soufan, A.T.; Bussen, M.; Schuster-Gossler K.; Harvey, R.P.; Moorman, A.F.; et al. Formation of the venous pole of the heart from an Nkx2-5-negative precursor population requires Tbx18. Circ. Res. 2006, 98, 1555-1563. [CrossRef]

113. Sun, Y.; Liang, X.; Najafi, N.; Cass, M.; Lin, L.; Cai, C.L.; Chen, J.; Evans, S.M. Islet 1 is expressed in distinct cardiovascular lineages, including pacemaker and coronary vascular cells. Dev. Biol. 2007, 304, 286-296. [CrossRef]

114. Liang, X.; Zhang, Q.; Cattaneo, P.; Zhuang, S.; Gong, X.; Spann, N.J.; Jiang, C.; Cao, X.; Zhao, X.; Zhang, X.; et al. Transcription factor ISL1 is essential for pacemaker development and function. J. Clin. Investig. 2015, 125, 3256-3268. [CrossRef]

115. Manner, J.; Merkel, N. Early morphogenesis of the sinuatrial region of the chick heart: A contribution to the understanding of the pathogenesis of direct pulmonary venous connections to the right atrium and atrial septal defects in hearts with right isomerism of the atrial appendages. Anat. Rec. 2007, 290, 168-180. [CrossRef]

116. Quiring, D.P. The development of the sino-atrial region of the chick heart. J. Morphol. 1933, 55, 81-118. [CrossRef]

117. Niderla-BieliŃska, J.; Jankowska-Steifer, E.; Flaht-Zabost, A.; Gula, G.; Czarnowska, E.; Ratajska, A. Proepicardium: Current Understanding of its Structure, Induction, and Fate. Anat. Rec. 2019, 302, 893-903. [CrossRef]

118. Maya-Ramos, L.; Cleland, J.; Bressan, M.; Mikawa, T. Induction of the Proepicardium. J. Dev. Biol. 2013, 1, 82-91. [CrossRef]

119. Schlueter, J.; Brand, T. Subpopulation of Proepicardial Cells Is Derived From the Somatic Mesoderm in the Chick Embryo. Circ. Res. 2013, 113, 1128-1137. [CrossRef]

120. Dueñas, A.; Aranega, A.E.; Franco, D. More than Just a Simple Cardiac Envelope; Cellular Contributions of the Epicardium. Front. Cell Dev. Biol. 2017, 5. [CrossRef]

121. Hamburger, V.; Hamilton, H.L. A series of normal stages in the development of the chick embryo. 1951. Dev. Dyn. 1992, 195, 231-272. [CrossRef]

122. Nguyen, T.P.; Qu, Z.; Weiss, J.N. Cardiac fibrosis and arrhythmogenesis: The road to repair is paved with perils. J. Mol. Cell Cardiol. 2014, 70, 83-91. [CrossRef] 
123. Tveito, A.; Lines, G.T. A condition for setting off ectopic waves in computational models of excitable cells. Math. Biosci. 2008, 213, 141-150. [CrossRef]

124. Xie, Y.; Sato, D.; Garfinkel, A.; Qu, Z.; Weiss, J.N. So little source, so much sink: Requirements for afterdepolarizations to propagate in tissue. Biophys. J. 2010, 99, 1408-1415. [CrossRef]

125. Fast, V.G.; Kléber, A.G. Block of impulse propagation at an abrupt tissue expansion: Evaluation of the critical strand diameter in 2- and 3-dimensional computer models. Cardiovasc. Res. 1995, 30, 449-459. [CrossRef]

126. Rohr, S.; Salzberg, B.M. Characterization of impulse propagation at the microscopic level across geometrically defined expansions of excitable tissue: Multiple site optical recording of transmembrane voltage (MSORTV) in patterned growth heart cell cultures. J. Gen. Physiol. 1994, 104, 287-309. [CrossRef]

127. Li, H.; Li, D.; Wang, Y.; Huang, Z.; Xu, J.; Yang, T.; Wang, L.; Tang, Q.; Cai, C.L.; Huang, H.; et al. Nkx2-5 defines a subpopulation of pacemaker cells and is essential for the physiological function of the sinoatrial node in mice. Development 2019, 146. [CrossRef]

128. Vedantham, V.; Galang, G.; Evangelista, M.; Deo, R.C.; Srivastava, D. RNA sequencing of mouse sinoatrial node reveals an upstream regulatory role for Islet-1 in cardiac pacemaker cells. Circ. Res. 2015, 116, 797-803. [CrossRef]

129. Van Eif, V.W.W.; Stefanovic, S.; van Duijvenboden, K.; Bakker, M.; Wakker, V.; de Gier-de Vries, C.; Zaffran, S.; Verkerk, A.O.; Boukens, B.J.; Christoffels, V.M. Transcriptome analysis of mouse and human sinoatrial node cells reveals a conserved genetic program. Development 2019, 146, dev173161-173129. [CrossRef]

130. Goodyer, W.R.; Beyersdorf, B.M.; Paik, D.T.; Tian, L.; Li, G.; Buikema, J.W.; Chirikian, O.; Choi, S.; Venkatraman, S.; Adams, E.L.; et al. Transcriptomic Profiling of the Developing Cardiac Conduction System at Single-Cell Resolution. Circ. Res. 2019, 125, 379-397. [CrossRef]

131. Linscheid, N.; Logantha, S.J.R.J.; Poulsen, P.C.; Zhang, S.; Schrölkamp, M.; Egerod, K.L.; Thompson, J.J.; Kitmitto, A.; Galli, G.; Humphries, M.J.; et al. Quantitative proteomics and single-nucleus transcriptomics of the sinus node elucidates the foundation of cardiac pacemaking. Nat. Commun. 2019, 10, 1-19. [CrossRef]

132. Brennan, J.A.; Chen, Q.; Gams, A.; Dyavanapalli, J.; Mendelowitz, D.; Peng, W.; Efimov, I.R. Evidence of Superior and Inferior Sinoatrial Nodes in the Mammalian Heart. JACC Clin. Electrophysiol. 2020, 6, 1827-1840. [CrossRef]

133. Kruithof, B.P.; Duim, S.N.; Moerkamp, A.T.; Goumans, M.J. TGF $\beta$ and BMP signaling in cardiac cushion formation: Lessons from mice and chicken. Differentiation 2012, 84, 89-102. [CrossRef]

134. Dronkers, E.; Wauters, M.M.M.; Goumans, M.J.; Smits, A.M. Epicardial TGF $\beta$ and BMP Signaling in Cardiac Regeneration: What Lesson Can We Learn from the Developing Heart? Biomolecules 2020, 10, 404. [CrossRef] [PubMed]

135. Garside, V.C.; Chang, A.C.; Karsan, A.; Hoodless, P.A. Co-ordinating Notch, BMP, and TGF- $\beta$ signaling during heart valve development. Cell. Mol. Life Sci. 2013, 70, 2899-2917. [CrossRef] [PubMed]

136. Euler-Taimor, G.; Heger, J. The complex pattern of SMAD signaling in the cardiovascular system. Cardiovasc. Res. 2006, 69, 15-25. [CrossRef] [PubMed]

137. Conway, S.J.; Doetschman, T.; Azhar, M. The Inter-Relationship of Periostin, TGF $\beta$, and BMP in Heart Valve Development and Valvular Heart Diseases. Sci. World J. 2011, 11, 574370. [CrossRef]

138. Van Wijk, B.; Moorman, A.F.M.; van den Hoff, M.J.B. Role of bone morphogenetic proteins in cardiac differentiation. Cardiovasc. Res. 2007, 74, 244-255. [CrossRef]

139. Hanna, A.; Frangogiannis, N.G. The Role of the TGF- $\beta$ Superfamily in Myocardial Infarction. Front. Cardiovasc. Med. 2019, 6. [CrossRef]

140. Jiao, K.; Langworthy, M.; Batts, L.; Brown, C.B.; Moses, H.L.; Baldwin, H.S. Tgfbeta signaling is required for atrioventricular cushion mesenchyme remodeling during in vivo cardiac development. Development 2006, 133, 4585-4593. [CrossRef]

141. Morabito, C.J.; Dettman, R.W.; Kattan, J.; Collier, J.M.; Bristow, J. Positive and negative regulation of epicardial-mesenchymal transformation during avian heart development. Dev. Biol. 2001, 234, 204-215. [CrossRef]

142. Person, A.D.; Klewer, S.E.; Runyan, R.B. Cell biology of cardiac cushion development. Int. Rev. Cytol 2005, 243, 287-335. [CrossRef]

143. Ishii, Y.; Garriock, R.J.; Navetta, A.M.; Coughlin, L.E.; Mikawa, T. BMP Signals Promote Proepicardial Protrusion Necessary for Recruitment of Coronary Vessel and Epicardial Progenitors to the Heart. Dev. Cell 2010, 19, 307-316. [CrossRef]

144. Hill, C.R.; Sanchez, N.S.; Love, J.D.; Arrieta, J.A.; Hong, C.C.; Brown, C.B.; Austin, A.F.; Barnett, J.V. BMP2 signals loss of epithelial character in epicardial cells but requires the Type III TGF $\beta$ receptor to promote invasion. Cell. Signal. 2012, 24, 1012-1022. [CrossRef]

145. Craig, E.A.; Austin, A.F.; Vaillancourt, R.R.; Barnett, J.V.; Camenisch, T.D. TGFß2-mediated production of hyaluronan is important for the induction of epicardial cell differentiation and invasion. Exp. Cell Res. 2010, 316, 3397-3405. [CrossRef]

146. De Laughter, D.M.; Clark, C.R.; Christodoulou, D.C.; Seidman, C.E.; Baldwin, H.S.; Seidman, J.G.; Barnett, J.V. Transcriptional Profiling of Cultured, Embryonic Epicardial Cells Identifies Novel Genes and Signaling Pathways Regulated by TGF $\beta$ R3 In Vitro. PLoS ONE 2016, 11, e0159710. [CrossRef]

147. Gluck, J.M.; Herren, A.W.; Yechikov, S.; Kao, H.K.J.; Khan, A.; Phinney, B.S.; Chiamvimonvat, N.; Chan, J.W.; Lieu, D.K. Biochemical and biomechanical properties of the pacemaking sinoatrial node extracellular matrix are distinct from contractile left ventricular matrix. PLoS ONE 2017, 12, e0185125. [CrossRef]

148. Yanni, J.; Tellez, J.O.; Sutyagin, P.V.; Boyett, M.R.; Dobrzynski, H. Structural remodelling of the sinoatrial node in obese old rats. J. Mol. Cell. Cardiol. 2010, 48, 653-662. [CrossRef] 
149. De Laughter, D.M.; Christodoulou, D.C.; Robinson, J.Y.; Seidman, C.E.; Baldwin, H.S.; Seidman, J.G.; Barnett, J.V. Spatial transcriptional profile of the chick and mouse endocardial cushions identify novel regulators of endocardial EMT in vitro. J. Mol. Cell. Cardiol. 2013, 59, 196-204. [CrossRef]

150. Schroeder, J.A.; Jackson, L.F.; Lee, D.C.; Camenisch, T.D. Form and function of developing heart valves: Coordination by extracellular matrix and growth factor signaling. J. Mol. Med. 2003, 81, 392-403. [CrossRef]

151. Singh, R.; Hoogaars, W.M.; Barnett, P.; Grieskamp, T.; Rana, M.S.; Buermans, H.; Farin, H.F.; Petry, M.; Heallen, T.; Martin, J.F.; et al. Tbx2 and Tbx3 induce atrioventricular myocardial development and endocardial cushion formation. Cell Mol. Life Sci. 2012, 69, 1377-1389. [CrossRef]

152. Bujak, M.; Frangogiannis, N.G. The role of TGF-beta signaling in myocardial infarction and cardiac remodeling. Cardiovasc. Res. 2007, 74, 184-195. [CrossRef]

153. Mezzano, V.; Liang, Y.; Wright, A.T.; Lyon, R.C.; Pfeiffer, E.; Song, M.Y.; Gu, Y.; Dalton, N.D.; Scheinman, M.; Peterson, K.L.; et al. Desmosomal junctions are necessary for adult sinus node function. Cardiovasc. Res. 2016, 111, 274-286. [CrossRef]

154. Desmoulière, A.; Geinoz, A.; Gabbiani, F.; Gabbiani, G. Transforming growth factor-beta 1 induces alpha-smooth muscle actin expression in granulation tissue myofibroblasts and in quiescent and growing cultured fibroblasts. J. Cell Biol. 1993, 122, $103-111$. [CrossRef]

155. Wang, S.; Sun, A.; Li, L.; Zhao, G.; Jia, J.; Wang, K.; Ge, J.; Zou, Y. Up-regulation of BMP-2 antagonizes TGF- $\beta 1 /$ ROCK-enhanced cardiac fibrotic signalling through activation of Smurf1/Smad6 complex. J. Cell Mol. Med. 2012, 16, 2301-2310. [CrossRef]

156. Chen, X.; Xu, J.; Jiang, B.; Liu, D. Bone Morphogenetic Protein-7 Antagonizes Myocardial Fibrosis Induced by Atrial Fibrillation by Restraining Transforming Growth Factor- $\beta$ (TGF- $\beta$ )/Smads Signaling. Med. Sci. Monit. 2016, 22, 3457-3468. [CrossRef]

157. Morine, K.J.; Qiao, X.; York, S.; Natov, P.S.; Paruchuri, V.; Zhang, Y.; Aronovitz, M.J.; Karas, R.H.; Kapur, N.K. Bone Morphogenetic Protein 9 Reduces Cardiac Fibrosis and Improves Cardiac Function in Heart Failure. Circulation 2018, 138, 513-526. [CrossRef]

158. Greenspon, A.J.; Patel, J.D.; Lau, E.; Ochoa, J.A.; Frisch, D.R.; Ho, R.T.; Pavri, B.B.; Kurtz, S.M. Trends in Permanent Pacemaker Implantation in the United States From 1993 to 2009. J. Am. Coll. Cardiol. 2012, 60, 1540-1545. [CrossRef]

159. Mond, H.G.; Proclemer, A. The 11th world survey of cardiac pacing and implantable cardioverter-defibrillators: Calendar year 2009-A World Society of Arrhythmia's project. Pacing Clin. Electrophysiol. 2011, 34, 1013-1027. [CrossRef]

160. Miake, J.; Marbán, E.; Nuss, H.B. Biological pacemaker created by gene transfer. Nature 2002, 419, 132-133. [CrossRef]

161. Cingolani, E. Biological pacemakers: Ready for the clinic? Trends Cardiovasc. Med. 2015, 25, 674-675. [CrossRef]

162. Cingolani, E.; Goldhaber, J.I.; Marbán, E. Next-generation pacemakers: From small devices to biological pacemakers. Nat. Rev. Cardiol. 2017, 15, 139-150. [CrossRef]

163. Grijalva, S.I.; Gu, J.M.; Li, J.; Fernandez, N.; Fan, J.; Sung, J.H.; Lee, S.Y.; Herndon, C.; Buckley, E.M.; Park, S.J.; et al. Engineered Cardiac Pacemaker Nodes Created by TBX18 Gene Transfer Overcome Source-Sink Mismatch. Adv. Sci. 2019, 6, 1901099. [CrossRef]

164. Boink, G.J.J.; Verkerk, A.O.; van Amersfoorth, S.C.M.; Tasseron, S.J.; van der Rijt, R.; Bakker, D.; Linnenbank, A.C.; van der Meulen, J.; de Bakker, J.M.T.; Seppen, J.; et al. Engineering physiologically controlled pacemaker cells with lentiviral HCN4 gene transfer. J. Gene Med. 2008, 10, 487-497. [CrossRef] [PubMed]

165. Kashiwakura, Y.; Cho, H.C.; Barth, A.S.; Azene, E.; Marbán, E. Gene transfer of a synthetic pacemaker channel into the heart: A novel strategy for biological pacing. Circulation 2006, 114, 1682-1686. [CrossRef] [PubMed]

166. Hashem, S.I.; Claycomb, W.C. Genetic isolation of stem cell-derived pacemaker-nodal cardiac myocytes. Mol. Cell. Biochem. 2013, 383, 161-171. [CrossRef] [PubMed]

167. Chauveau, S.; Brink, P.R.; Cohen, I.S. Stem cell-based biological pacemakers from proof of principle to therapy: A review. J. Cytotherapy 2014, 16, 873-880. [CrossRef] [PubMed] 